\title{
Identifying the Pressure Points of Acute Cadmium Stress Prior to Acclimation in Arabidopsis thaliana
}

\author{
Jana Deckers ${ }^{1}$, Sophie Hendrix ${ }^{1}\left(\mathbb{D}\right.$, Els Prinsen ${ }^{2}$, Jaco Vangronsveld ${ }^{1}\left(\mathbb{D}\right.$ and Ann Cuypers ${ }^{1, *} \mathbb{C}$ \\ 1 Centre for Environmental Sciences, Hasselt University, Agoralaan Building D, 3590 Diepenbeek, Belgium; \\ jana.deckers@uhasselt.be (J.D.); sophie.hendrix@uhasselt.be (S.H.); jaco.vangronsveld@uhasselt.be (J.V.) \\ 2 Department of Biology, University of Antwerp, Groenenborgerlaan 171, 2020 Antwerpen, Belgium; \\ els.prinsen@uantwerpen.be \\ * Correspondence: ann.cuypers@uhasselt.be
}

Received: 14 July 2020; Accepted: 25 August 2020; Published: 28 August 2020

\begin{abstract}
The toxic metal cadmium (Cd) is a major soil pollutant. Knowledge on the acute Cd-induced stress response is required to better understand the triggers and sequence of events that precede plant acclimation. Therefore, we aimed to identify the pressure points of $\mathrm{Cd}$ stress using a short-term exposure set-up ranging from $0 \mathrm{~h}$ to $24 \mathrm{~h}$. Acute responses related to glutathione (GSH), hydrogen peroxide $\left(\mathrm{H}_{2} \mathrm{O}_{2}\right)$, 1-aminocyclopropane-1-carboxylic acid (ACC), ethylene and the oxidative challenge were studied at metabolite and/or transcript level in roots and leaves of Arabidopsis thaliana either exposed or not to $5 \mu \mathrm{M} \mathrm{Cd}$. Cadmium rapidly induced root GSH depletion, which might serve as an alert response and modulator of $\mathrm{H}_{2} \mathrm{O}_{2}$ signalling. Concomitantly, a stimulation of root ACC levels was observed. Leaf responses were delayed and did not involve GSH depletion. After $24 \mathrm{~h}$, a defined oxidative challenge became apparent, which was most pronounced in the leaves and concerted with a strong induction of leaf ACC synthesis. We suggest that root GSH depletion is required for a proper alert response rather than being a merely adverse effect. Furthermore, we propose that roots serve as command centre via a.o. root-derived ACC/ethylene to engage the leaves in a proper stress response.
\end{abstract}

Keywords: Arabidopsis thaliana; cadmium; acute responses; glutathione; hydrogen peroxide; 1-aminocyclopropane-1-carboxylic acid; ethylene; oxidative challenge

\section{Introduction}

Under the current circumstances, where the growing population is exceeding the global food supply, arable land is becoming sparse [1]. Soil pollution is putting even more restrictions on the availability of qualitative agricultural land. Trace metallic elements, like cadmium (Cd), significantly contribute to this pollution problem, as they are phytotoxic and pose risks to human health via the bioaccumulation in our food chain [2]. The study of short-term plant responses allows for the identification of the pressure points of a certain stressor and the early challenges that plants face prior to acclimation. Understanding the early stress-induced responses will help improve plant acclimation itself, allowing plants, and in particular crops, to reach their full potential even in suboptimal environments. The latter can be achieved by means of biotechnological and agro-ecological approaches which encompass a.o. genetic modifications and application of soil amendments, respectively.

Cadmium phytotoxicity mainly arises from its bioavailability and chemical similarity to essential elements like zinc, calcium and iron, enabling $\mathrm{Cd}$ to hitchhike along transporters for essential elements $[3,4]$. This results in disturbance of the homeostasis of these elements and in their displacement by $\mathrm{Cd}$ in biomolecules, rendering them inactive and, at the same time, freeing up redox-active metals like iron [3,5-7]. These redox-active metals directly stimulate reactive oxygen species (ROS) production, while $\mathrm{Cd}$ increases ROS production indirectly, via the stimulation of pro-oxidants like NADPH oxidases 
and the deprivation of the anti-oxidative system [8]. The anti-oxidative metabolite glutathione (GSH) is one of the prominent defence molecules in the responses to Cd stress and is synthesised in two ATP-dependent steps [9-11]. Firstly, glutamate is combined with cysteine, which is catalysed by glutamate cysteine ligase (GSH1) to produce $\gamma$-glutamylcysteine $(\gamma$-EC) [12]. Next, the addition of glycine is catalysed by GSH synthetase (GSH2) to form GSH $[13,14]$. The nucleophilic nature of the central thiol group enables GSH and its oligomers, termed phytochelatins (PCs), to chelate Cd and sequester it into the vacuole [15]. Concurrently, GSH serves to neutralise ROS, like hydrogen peroxide $\left(\mathrm{H}_{2} \mathrm{O}_{2}\right)$, directly but mainly through the ascorbate (AsA)-GSH cycle [16,17]. In this cycle, the NADPH-dependent enzyme glutathione reductase (GR) serves to maintain the reduced GSH pool [18]. Moreover, Mhamdi et al. (2010) showed that GR encoded by the GLUTATHIONE REDUCTASE 1 (GR1) isoform is crucial in the metabolism of $\mathrm{H}_{2} \mathrm{O}_{2}$ [19]. In the apoplastic space, however, it is rather unlikely that GSH functions as major anti-oxidant due to its relatively low abundance [20]. Nevertheless, it is clear from the literature that apoplastic GSH and its recycling fulfil other important roles that need further consideration [20-24]. The recycling of extracellular GSH (eGSH) is accomplished by the activity of $\gamma$-glutamyl transpeptidase (GGT) encoded by $\gamma$-GLUTAMYL TRANSPEPTIDASE 1 (GGT1), that catabolises eGSH into its constituent amino acids [24]. The hydrolysis of eGSH and glutathione S-conjugates enables the recovery of GSH intracellularly [24,25]. Furthermore, it is proposed that GGT plays a role in the redox control of the apoplastic space and serves to mitigate oxidative stress as a result of an unbalanced ROS production $[20,24,26]$. It is a well-known fact that ROS cannot simply be considered as detrimental compounds, as they often fulfil a signalling role [27]. Hydrogen peroxide, especially, is considered to be a central component of signal transduction due to its stability and ability to cross membranes [28]. Because of this double-edged sword, GSH does not serve merely to detoxify $\mathrm{H}_{2} \mathrm{O}_{2}$, but it is also key in the fine-tuning of $\mathrm{H}_{2} \mathrm{O}_{2}$-dependent signalling responses [29,30].

As demonstrated by Jozefczak et al. (2014), root GSH levels became strongly depleted upon $2 \mathrm{~h}$ of $\mathrm{Cd}(5 \mu \mathrm{M})$ exposure in hydroponics, which is attributable to the fact that GSH is allocated to PC synthesis [10]. This impacts the anti-oxidative capacity of GSH in the early responses to Cd stress. Moreover, the depletion of such a ubiquitous and considerable anti-oxidant will most likely trigger specific signalling events that define the acute responses and acclimation to $\mathrm{Cd}$ stress. Besides alterations in the GSH pool and $\mathrm{H}_{2} \mathrm{O}_{2}$ signalling, other components like phytohormones are key in the responses to environmental stresses. The important stress hormone ethylene was already demonstrated by Schellingen et al. (2015) to serve as key regulator in the responses to Cd stress [31]. More specifically, ethylene production and signalling are required for the stimulation of leaf GSH metabolism under Cd stress and stimulation of ROS-generating NADPH oxidases in general [31-34]. Ethylene production is known to increase under $\mathrm{Cd}$ stress and mainly relies on the transcriptional upregulation and post-transcriptional stabilisation of 1-aminocyclopropane-1-carboxylic acid (ACC) synthase (ACS) isoforms ACS2 and ACS6 [35]. These isozymes catalyse the conversion of S-adenosylmethionine (SAM), derived from methionine, to ACC, the direct precursor of ethylene [36,37]. It is known that ACS2 and ACS6 are targeted via the transcription factor WRKY33, by mitogen-activated protein kinase 3 (MPK3) and by MPK6, which, in turn, are phosphorylated by the oxidative-signal inducible 1 (OXI1) kinase, that becomes induced by $\mathrm{H}_{2} \mathrm{O}_{2}[31,38,39]$. These findings demonstrate that different signalling pathways are strongly intertwined in a complex network that defines the outcome of stress responses and acclimation thereafter.

In this study, a time-course analysis of different key regulators was conducted in order to unravel the sequence of events in terms of acute $\mathrm{Cd}$-induced responses. The use of a short-term exposure set-up, ranging from $0 \mathrm{~h}$ to $24 \mathrm{~h}$ of exposure, allowed for the identification of pressure points prior to acclimation. The identification of these pressure points is highly required in order to understand the hurdles a plant needs to overcome before reaching acclimation and contributes to the bigger picture in order to understand the process of acclimation to Cd stress. 


\section{Results}

Focussing on acute Cd-induced responses, both roots and leaves were separately studied during a short exposure time frame ranging from $0 \mathrm{~h}$ to $24 \mathrm{~h}$. The use of an optimised hydroponic cultivation system allowed the controlled exposure of $A$. thaliana wild-type (WT) plants to a sublethal and environmentally relevant $\mathrm{Cd}$ concentration of $5 \mu \mathrm{M}[40,41]$.

\subsection{Cadmium-Induced Growth Responses and Cadmium Accumulation}

Fresh weight (Figure 1), dry weight (Figure S1) and Cd concentration (Table 1) were compared between Cd-exposed and unexposed WT plants within the short exposure time frame. Acute exposure did not have a negative impact on the root and leaf fresh weight and dry weight of WT A. thaliana plants (Figure 1 and Figure S1). Cadmium uptake and translocation, however, had an early onset, which was reflected by the significant increase in Cd concentrations observed in both organs $2 \mathrm{~h}$ after the start of exposure (Table 1).

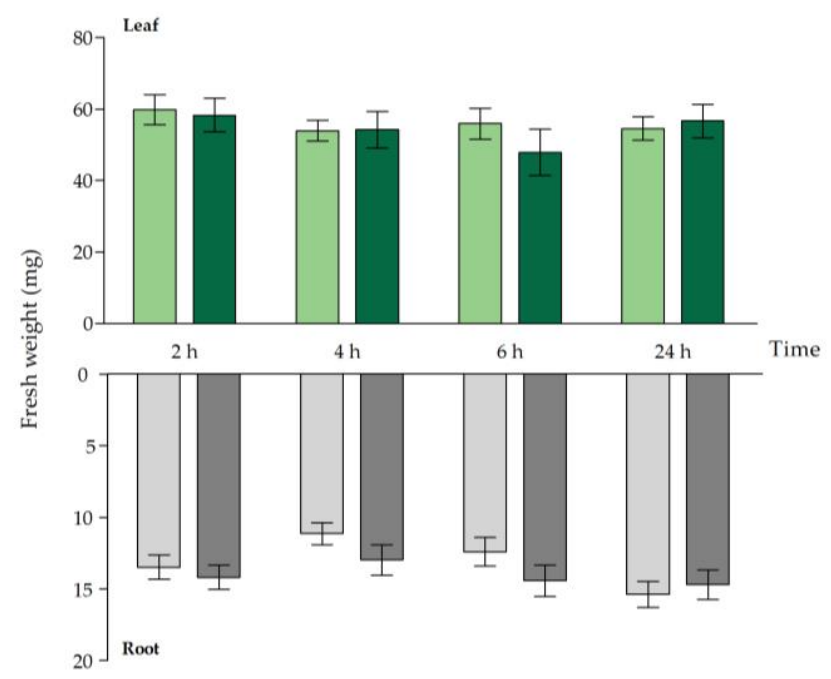

Figure 1. Rosette (green bars) and root (grey bars) fresh weight (mg) of Arabidopsis thaliana plants grown under control conditions $(0 \mu \mathrm{M} \mathrm{CdSO} 4$, light bars) or exposed to $5 \mu \mathrm{M} \mathrm{CdSO} 4$ (dark bars) during $2 \mathrm{~h}, 4 \mathrm{~h}, 6 \mathrm{~h}$ and $24 \mathrm{~h}$ after 3 weeks of growth. For each time point, data represent the mean \pm S.E. of eight biological independent replicates. No significant differences ( $t$-test: $p<0.05)$ were observed between control and exposed plants, within each time point.

Generally, Cd concentrations were higher in roots than in leaves. Both root and leaf Cd concentrations increased significantly in a time-dependent manner and especially after 24 strong increases were observed in both organs (Table 1). Similar to the Cd concentrations in both organs, the translocation of $\mathrm{Cd}$ from root to shoot increased time-dependently, and after $24 \mathrm{~h}$ a translocation factor of almost $50 \%$ was reached (Table 1 ). This means that $50 \%$ of the $\mathrm{Cd}$ taken up by the roots was translocated to the aerial part of the plant. In our study, $\mathrm{Cd}$ translocation had an early onset and, even though $\mathrm{Cd}$ translocation is important in the detoxification of $\mathrm{Cd}, \mathrm{PC}$ synthesis is the major determinant of $\mathrm{Cd}$ sensitivity in general [42]. 
Table 1. Cadmium concentrations ( $\mathrm{mg} \mathrm{kg}^{-1}$ dry weight) in leaves and roots and the translocation factor (\%) of Arabidopsis thaliana plants grown under control conditions $\left(0 \mu \mathrm{M} \mathrm{CdSO}_{4}\right)$ or exposed to $5 \mu \mathrm{M}$ $\mathrm{CdSO}_{4}$ during $2 \mathrm{~h}, 4 \mathrm{~h}, 6 \mathrm{~h}, 24 \mathrm{~h}$ after 3 weeks of growth. For each time point, data represent the mean \pm S.E. of four biological independent replicates. Significant differences $(t$-test: $p<0.05)$ between control and exposed plants, within each time point, are marked in green. Significant differences over time are indicated with different letters (one-way ANOVA: $p<0.05$ ). LOD: Cd levels below limit of detection $(<10 \mathrm{ppb})$.

\begin{tabular}{|c|c|c|c|c|c|}
\hline \multicolumn{6}{|c|}{ Cd Concentration (mg kg-1 DW) } \\
\hline Organ & {$\left[\mathrm{CdSO}_{4}\right]$} & $2 \mathrm{~h}$ & $4 \mathrm{~h}$ & $6 \mathrm{~h}$ & $24 \mathrm{~h}$ \\
\hline \multirow{2}{*}{ Leaf } & $0 \mu \mathrm{M}$ & $0.68 \pm 0.12$ & $0.62 \pm 0.16$ & $0.65 \pm 0.09$ & $0.90 \pm 0.17$ \\
\hline & $5 \mu \mathrm{M}$ & $6.86 \pm 0.17^{\mathrm{a}}$ & $61.01 \pm 2.73^{b}$ & $152.97 \pm 4.84^{\mathrm{c}}$ & $840.24 \pm 11.71^{d}$ \\
\hline \multirow{2}{*}{ Root } & $0 \mu \mathrm{M}$ & LOD & LOD & LOD & LOD \\
\hline & $5 \mu \mathrm{M}$ & $536.44 \pm 14.24^{\mathrm{a}}$ & $620.39 \pm 13.40^{b}$ & $730.78 \pm 14.25^{\mathrm{C}}$ & $1788.57 \pm 65.40^{d *}$ \\
\hline \multicolumn{6}{|c|}{ Translocation Factor } \\
\hline & {$\left[\mathrm{CdSO}_{4}\right]$} & $2 \mathrm{~h}$ & $4 \mathrm{~h}$ & $6 \mathrm{~h}$ & $24 \mathrm{~h}$ \\
\hline & $5 \mu \mathrm{M}$ & $1.28 \pm 0.04^{\mathrm{a}}$ & $9.86 \pm 0.53^{b}$ & $21.00 \pm 0.97^{c}$ & $47.24 \pm 1.88^{d}$ \\
\hline
\end{tabular}

\subsection{Glutathione as Chelator and Anti-Oxidant}

The chelation of Cd by PCs followed by vacuolar sequestration is a well-characterised mechanism of $\mathrm{Cd}$ detoxification [15]. In this study, the allocation of GSH to PC synthesis was reflected by a significant depletion of GSH in the roots after $2 \mathrm{~h}$ of exposure (Figure 2), which was also demonstrated by Jozefczak et al. (2014) [10]. After $4 \mathrm{~h}$ of exposure, GSH depletion became even more pronounced and the root GSH levels dropped below $40 \%$ of GSH levels in control plants. After $6 \mathrm{~h}$ of exposure, a turning point was observed and root GSH levels revealed an increasing trend. While GSH concentrations were still significantly decreased after $6 \mathrm{~h}$ of exposure, they were fully recovered to control levels after $24 \mathrm{~h}$ (Figure 2).

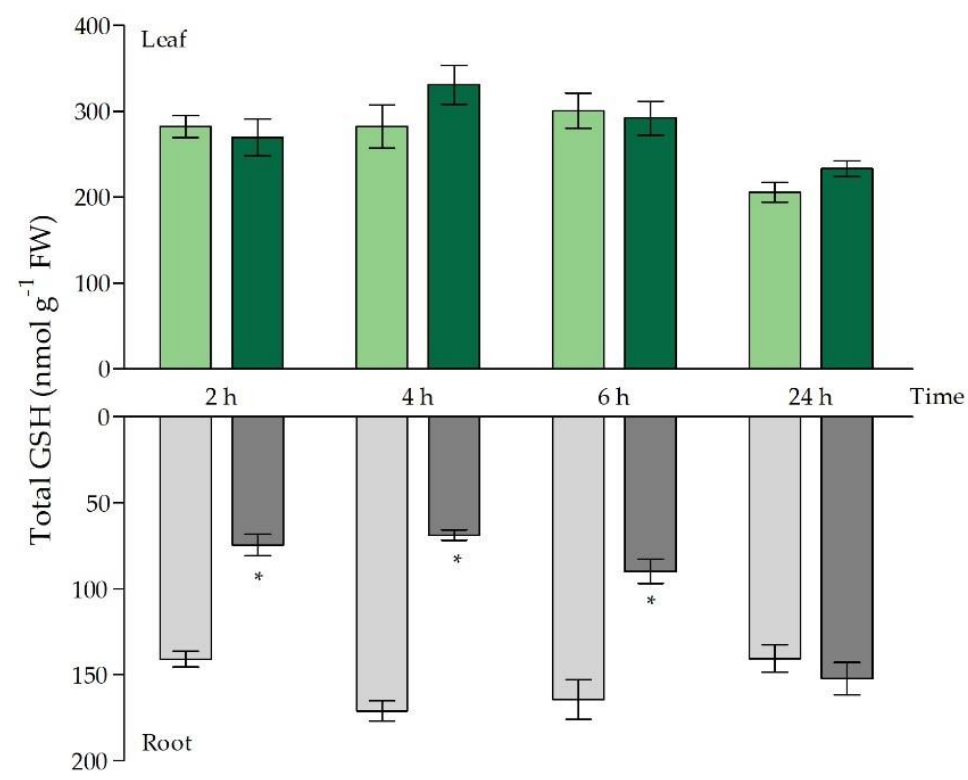

Figure 2. Total glutathione (GSH) concentrations ( $\mathrm{nmol} \mathrm{g}^{-1}$ fresh weight) in leaves (green bars) and roots (grey bars) of Arabidopsis thaliana plants grown under control conditions $(0 \mu \mathrm{M} \mathrm{CdSO} 4$, light bars) or exposed to $5 \mu \mathrm{M}$ CdSO 4 (dark bars) during $2 \mathrm{~h}, 4 \mathrm{~h}, 6 \mathrm{~h}$ and $24 \mathrm{~h}$ after 3 weeks of growth. For each time point, data represent the mean \pm S.E. of four biological independent replicates. Significant differences ( $t$-test: $p<0.05)$ between control and exposed plants, within each time point, are indicated with an asterisk $\left(^{*}\right)$. 
This recovery of root GSH levels starting from $6 \mathrm{~h}$ of exposure coincided with a significantly increased expression of GSH metabolism genes (GSH1, GSH2 and GR1) (Table 2). In leaves of Cd-exposed plants, the depletion in GSH levels was not observed (Figure 2). In fact, GSH levels remained unchanged, and the expression of metabolism genes was higher after $24 \mathrm{~h}$ of exposure (Table 2). Even though total root GSH concentrations fluctuated to a great extent throughout the short-term Cd exposure, the percentages of reduced GSH remained tightly controlled. More specifically, over $90 \%$ of the GSH pool occurred in its reduced form, and this was maintained at each time point in both organs (Table S1). Furthermore, only limited fluctuations in GR activity were observed (Table 3). A limited decrease in GR activity occurred after $2 \mathrm{~h}$ of $\mathrm{Cd}$ exposure in the roots, and a significant increase in activity became apparent after $24 \mathrm{~h}$ of exposure. In the leaves, GR activity was significantly elevated after $6 \mathrm{~h}$ and $24 \mathrm{~h}$ of $\mathrm{Cd}$ exposure (Table 3).

Table 2. Transcript levels of glutathione (GSH)-related genes in leaves and roots of Arabidopsis thaliana plants grown under control conditions $\left(0 \mu \mathrm{M} \mathrm{CdSO}_{4}\right)$ or exposed to $5 \mu \mathrm{M} \mathrm{CdSO}$ during $2 \mathrm{~h}, 4 \mathrm{~h}$, $6 \mathrm{~h}$ and $24 \mathrm{~h}$ after 3 weeks of growth. For each time point, data are given as the mean \pm S.E. of four biological replicates relative to the control set at 1.00. Significant differences ( $t$-test: $p<0.05$ ) between control and exposed plants, within each time point, are marked in colour (upregulated: $\square$ ). GSH1: $\gamma$-glutamylcysteine synthetase; GSH2: GSH synthetase; GR1: glutathione reductase; GGT1: $\gamma$-glutamyl transpeptidase 1; ZAT6: zinc finger of Arabidopsis thaliana 6.

\begin{tabular}{|c|c|c|c|c|c|}
\hline \multicolumn{6}{|c|}{ GSH-Related Genes } \\
\hline Gene & {$\left[\mathrm{CdSO}_{4}\right]$} & $2 \mathrm{~h}$ & $4 \mathrm{~h}$ & $6 \mathrm{~h}$ & $24 \mathrm{~h}$ \\
\hline \multicolumn{6}{|l|}{ Leaf } \\
\hline \multirow{2}{*}{ GSH1 } & $0 \mu \mathrm{M}$ & $1.00 \pm 0.16$ & $1.00 \pm 0.06$ & $1.00 \pm 0.13$ & $1.00 \pm 0.04$ \\
\hline & $5 \mu \mathrm{M}$ & $0.75 \pm 0.13$ & $0.91 \pm 0.05$ & $0.79 \pm 0.12$ & $1.77 \pm 0.19$ \\
\hline \multirow{2}{*}{ GSH2 } & $0 \mu \mathrm{M}$ & $1.00 \pm 0.06$ & $1.00 \pm 0.04$ & $1.00 \pm 0.06$ & $1.00 \pm 0.04$ \\
\hline & $5 \mu \mathrm{M}$ & $0.77 \pm 0.11$ & $0.91 \pm 0.10$ & $0.90 \pm 0.06$ & $2.74 \pm 0.14$ \\
\hline \multirow{2}{*}{ GR1 } & $0 \mu \mathrm{M}$ & $1.00 \pm 0.04$ & $1.00 \pm 0.07$ & $1.00 \pm 0.20$ & $1.00 \pm 0.10$ \\
\hline & $5 \mu \mathrm{M}$ & $0.81 \pm 0.08$ & $1.05 \pm 0.08$ & $0.87 \pm 0.13$ & $3.15 \pm 0.52$ \\
\hline \multirow{2}{*}{ GGT1 } & $0 \mu \mathrm{M}$ & $1.00 \pm 0.26$ & $1.00 \pm 0.06$ & $1.00 \pm 0.27$ & $1.00 \pm 0.10$ \\
\hline & $5 \mu \mathrm{M}$ & $0.82 \pm 0.12$ & $1.34 \pm 0.19$ & $1.47 \pm 0.43$ & $4.60 \pm 0.85$ \\
\hline \multirow{2}{*}{ ZAT6 } & $0 \mu \mathrm{M}$ & $1.00 \pm 0.20$ & $1.00 \pm 0.22$ & $1.00 \pm 0.08$ & $1.00 \pm 0.30$ \\
\hline & $5 \mu \mathrm{M}$ & $0.93 \pm 0.14$ & $1.14 \pm 0.28$ & $1.55 \pm 0.09$ & $15.06 \pm 0.55$ \\
\hline \multicolumn{6}{|l|}{ Root } \\
\hline \multirow{2}{*}{ GSH1 } & $0 \mu \mathrm{M}$ & $1.00 \pm 0.22$ & $1.00 \pm 0.16$ & $1.00 \pm 0.10$ & $1.00 \pm 0.17$ \\
\hline & $5 \mu \mathrm{M}$ & $2.08 \pm 0.45$ & $1.35 \pm 0.05$ & $1.63 \pm 0.06$ & $4.67 \pm 0.28$ \\
\hline \multirow{2}{*}{ GSH2 } & $0 \mu \mathrm{M}$ & $1.00 \pm 0.15$ & $1.00 \pm 0.11$ & $1.00 \pm 0.01$ & $1.00 \pm 0.09$ \\
\hline & $5 \mu \mathrm{M}$ & $1.67 \pm 0.01$ & $1.31 \pm 0.11$ & $1.44 \pm 0.08$ & $2.85 \pm 0.20$ \\
\hline \multirow{2}{*}{ GR1 } & $0 \mu \mathrm{M}$ & $1.00 \pm 0.13$ & $1.00 \pm 0.02$ & $1.00 \pm 0.04$ & $1.00 \pm 0.04$ \\
\hline & $5 \mu \mathrm{M}$ & $1.01 \pm 0.09$ & $0.88 \pm 0.07$ & $1.36 \pm 0.03$ & $2.06 \pm 0.19$ \\
\hline \multirow{2}{*}{ GGT1 } & $0 \mu \mathrm{M}$ & $1.00 \pm 0.16$ & $1.00 \pm 0.14$ & $1.00 \pm 0.07$ & $1.00 \pm 0.13$ \\
\hline & $5 \mu \mathrm{M}$ & $1.72 \pm 0.11$ & $1.67 \pm 0.12$ & $2.00 \pm 0.26$ & $5.07 \pm 0.02$ \\
\hline \multirow{2}{*}{ ZAT6 } & $0 \mu \mathrm{M}$ & $1.00 \pm 0.16$ & $1.00 \pm 0.13$ & $1.00 \pm 0.16$ & $1.00 \pm 0.15$ \\
\hline & $5 \mu \mathrm{M}$ & $1.10 \pm 0.19$ & $1.29 \pm 0.21$ & $1.94 \pm 0.02$ & $2.89 \pm 0.55$ \\
\hline
\end{tabular}

As reported in literature, no GR activity was detected in the apoplastic space, and GSH recycling was carried out by GGT1-encoded GGT [25]. Because the concentration of GSH in the apoplast is relatively low, AsA is more likely to fulfil the role as major anti-oxidant [20]. However, eGSH and its recycling by GGT have been implemented in the mitigation of oxidative stress and were demonstrated to be important in the modulation of stress signalling [21]. In our study, a strong and early transcriptional induction was observed for GGT1 at the root level (Table 2). 
Table 3. Glutathione reductase (GR) activity ( $\mathrm{mU} \mathrm{g}^{-1}$ fresh weight) in leaves and roots of Arabidopsis thaliana plants grown under control conditions $\left(0 \mu \mathrm{M} \mathrm{CdSO}_{4}\right)$ or exposed to $5 \mu \mathrm{M} \mathrm{CdSO}_{4}$ during $2 \mathrm{~h}$, $4 \mathrm{~h}, 6 \mathrm{~h}$ and $24 \mathrm{~h}$ after 3 weeks of growth. For each time point, data represent the mean \pm S.E. of four biological independent replicates. Significant differences ( $t$-test: $p<0.05)$ between control and exposed plants, within each time point, are marked in colour (increased: $\square$, increased: $\square$ ).

\begin{tabular}{ccccc}
\hline \multicolumn{5}{c}{ GR activity $\left(\mathbf{m U} \mathbf{g}^{-\mathbf{1}} \mathbf{F W}\right)$} \\
\hline$\left[\mathrm{CdSO}_{4}\right]$ & $\mathbf{2 ~ h}$ & $\mathbf{4} \mathbf{h}$ & $\mathbf{6 ~ h}$ & $\mathbf{2 4} \mathbf{~ h}$ \\
\hline Leaf & & & \\
\hline $0 \mu \mathrm{M}$ & $64.46 \pm 1.75$ & $68.08 \pm 0.08$ & $65.33 \pm 0.93$ & $57.02 \pm 1.55$ \\
$5 \mu \mathrm{M}$ & $64.52 \pm 0.86$ & $65.70 \pm 1.94$ & $70.48 \pm 1.53$ & $69.70 \pm 4.62$ \\
\hline Root & & & \\
\hline $0 \mu \mathrm{M}$ & $33.82 \pm 1.01$ & $32.23 \pm 1.67$ & $31.50 \pm 1.26$ & $30.56 \pm 0.11$ \\
$5 \mu \mathrm{M}$ & $30.16 \pm 0.86$ & $29.60 \pm 0.74$ & $30.91 \pm 0.57$ & $39.05 \pm 0.93$ \\
\hline
\end{tabular}

\subsection{ROS Signalling and Oxidative Challenge under Acute Cd Stress}

In roots, the transcriptional profile of the ROS-producing NADPH oxidases Respiratory Burst Oxidase Homologues D and $\mathrm{F}$ ( $R B O H D$ and $R B O H F$, Table 4) showed an early and significant induction after $2 \mathrm{~h}$, which remained elevated throughout the entire $24 \mathrm{~h} \mathrm{Cd}$ exposure period. A similar expression pattern was observed for $R B O H C$ but its induction had already disappeared after $24 \mathrm{~h}$ (Table 4). Oxidative stress, as indicated by the induction of oxidative stress markers [43], had a delayed onset at the root level and occurred to a smaller extent as compared to the leaves. More specifically, oxidative stress markers and related genes (i.e., ZINC FINGER OF ARABIDOPSIS THALIANA 12 (ZAT12) and REDOX-RESPONSIVE TRANSCRIPTION FACTOR 1 (RRTF1)) were significantly induced or, at least, showed an increasing trend but only upon $24 \mathrm{~h}$ of $\mathrm{Cd}$ exposure (Table 4 ).

Table 4. Transcript levels of prominent NADPH oxidases and oxidative stress-related genes in leaves and roots of Arabidopsis thaliana plants grown under control conditions $\left(0 \mu \mathrm{M} \mathrm{CdSO}_{4}\right)$ or exposed to $5 \mu \mathrm{M} \mathrm{CdSO}_{4}$ during $2 \mathrm{~h}, 4 \mathrm{~h}, 6 \mathrm{~h}$ and $24 \mathrm{~h}$ after 3 weeks of growth. For each time point, data are given as the mean \pm S.E. of four biological replicates relative to the control set at 1.00 . Significant differences ( $t$-test: $p<0.05$ ) between control and exposed plants, within each time point, are marked in colour (upregulated: $\square$, downregulated: $\square$ ). $R B O H$ : respiratory burst oxidase homologue; ZAT12: zinc finger of Arabidopsis thaliana 12; RRTF1: redox-responsive transcription factor 1.

\begin{tabular}{cccccc}
\hline \multicolumn{7}{c}{ NADPH Oxidases } \\
\hline Gene & {$\left[\mathrm{CdSO}_{4}\right]$} & $\mathbf{2 ~ h}$ & $\mathbf{4 h}$ & $\mathbf{6} \mathbf{h}$ & $\mathbf{2 4} \mathbf{h}$ \\
\hline Leaf & & & & & \\
\hline \multirow{2}{*}{ RBOHC } & $0 \mu \mathrm{M}$ & $1.00 \pm 0.05$ & $1.00 \pm 0.06$ & $1.00 \pm 0.14$ & $1.00 \pm 0.25$ \\
& $5 \mu \mathrm{M}$ & $1.01 \pm 0.26$ & $10.33 \pm 4.58$ & $3.35 \pm 1.93$ & $56.48 \pm 8.23$ \\
\hline \multirow{2}{*}{ RBOHD } & $0 \mu \mathrm{M}$ & $1.00 \pm 0.25$ & $1.00 \pm 0.08$ & $1.00 \pm 0.12$ & $1.00 \pm 0.07$ \\
& $5 \mu \mathrm{M}$ & $0.62 \pm 0.02$ & $1.29 \pm 0.22$ & $1.60 \pm 0.28$ & $1.61 \pm 0.13$ \\
\hline \multirow{2}{*}{ RBOHF } & $0 \mu \mathrm{M}$ & $1.00 \pm 0.11$ & $1.00 \pm 0.10$ & $1.00 \pm 0.18$ & $1.00 \pm 0.08$ \\
& $5 \mu \mathrm{M}$ & $1.40 \pm 0.02$ & $1.04 \pm 0.13$ & $1.18 \pm 0.30$ & $2.53 \pm 0.55$ \\
\hline
\end{tabular}


Table 4. Cont.

\begin{tabular}{|c|c|c|c|c|c|}
\hline \multicolumn{6}{|c|}{ NADPH Oxidases } \\
\hline Gene & {$\left[\mathrm{CdSO}_{4}\right]$} & $2 \mathrm{~h}$ & $4 \mathrm{~h}$ & $6 \mathrm{~h}$ & $24 \mathrm{~h}$ \\
\hline \multicolumn{6}{|l|}{ Root } \\
\hline \multirow{2}{*}{$\mathrm{RBOHC}$} & $0 \mu \mathrm{M}$ & $1.00 \pm 0.10$ & $1.00 \pm 0.11$ & $1.00 \pm 0.14$ & $1.00 \pm 0.23$ \\
\hline & $5 \mu \mathrm{M}$ & $1.41 \pm 0.11$ & $1.65 \pm 0.07$ & $1.48 \pm 0.09$ & $0.72 \pm 0.08$ \\
\hline \multirow{2}{*}{ RBOHD } & $0 \mu \mathrm{M}$ & $1.00 \pm 0.06$ & $1.00 \pm 0.14$ & $1.00 \pm 0.10$ & $1.00 \pm 0.14$ \\
\hline & $5 \mu \mathrm{M}$ & $1.63 \pm 0.09$ & $1.74 \pm 0.13$ & $1.60 \pm 0.05$ & $2.48 \pm 0.35$ \\
\hline \multirow{2}{*}{ RBOHF } & $0 \mu \mathrm{M}$ & $1.00 \pm 0.12$ & $1.00 \pm 0.10$ & $1.00 \pm 0.05$ & $1.00 \pm 0.17$ \\
\hline & $5 \mu \mathrm{M}$ & $1.74 \pm 0.09$ & $1.54 \pm 0.09$ & $1.34 \pm 0.07$ & $2.53 \pm 0.14$ \\
\hline \multicolumn{6}{|c|}{ Oxidative Stress Markers and Related Genes } \\
\hline \multicolumn{6}{|l|}{ Leaf } \\
\hline \multirow{2}{*}{ AT1G05340 } & $0 \mu \mathrm{M}$ & $1.00 \pm 0.05$ & $1.00 \pm 0.04$ & $1.00 \pm 0.15$ & $1.00 \pm 0.18$ \\
\hline & $5 \mu \mathrm{M}$ & $1.67 \pm 0.73$ & $1.95 \pm 0.17$ & $2.18 \pm 0.68$ & $53.23 \pm 12.52$ \\
\hline \multirow{2}{*}{ AT1G19020 } & $0 \mu \mathrm{M}$ & $1.00 \pm 0.30$ & $1.00 \pm 0.08$ & $1.00 \pm 0.13$ & $1.00 \pm 0.18$ \\
\hline & $5 \mu \mathrm{M}$ & $1.19 \pm 0.57$ & $5.22 \pm 1.97$ & $3.20 \pm 0.32$ & $36.20 \pm 7.13$ \\
\hline \multirow{2}{*}{ AT1G57630 } & $0 \mu \mathrm{M}$ & $1.00 \pm 0.07$ & $1.00 \pm 0.07$ & $1.00 \pm 0.08$ & $1.00 \pm 0.13$ \\
\hline & $5 \mu \mathrm{M}$ & $1.78 \pm 0.97$ & $10.67 \pm 5.73$ & $2.45 \pm 1.31$ & $30.33 \pm 3.42$ \\
\hline \multirow{2}{*}{ AT2G21640 } & $0 \mu \mathrm{M}$ & $1.00 \pm 0.05$ & $1.00 \pm 0.07$ & $1.00 \pm 0.09$ & $1.00 \pm 0.21$ \\
\hline & $5 \mu \mathrm{M}$ & $0.83 \pm 0.06$ & $1.09 \pm 0.17$ & $0.61 \pm 0.11$ & $8.42 \pm 1.33$ \\
\hline \multirow{2}{*}{ AT2G43510 } & $0 \mu \mathrm{M}$ & $1.00 \pm 0.02$ & $1.00 \pm 0.08$ & $1.00 \pm 0.20$ & $1.00 \pm 0.12$ \\
\hline & $5 \mu \mathrm{M}$ & $0.64 \pm 0.14$ & $1.25 \pm 0.33$ & $0.88 \pm 0.14$ & $26.36 \pm 4.00$ \\
\hline \multirow{2}{*}{ ZAT12 } & $0 \mu \mathrm{M}$ & $1.00 \pm 0.32$ & $1.00 \pm 0.17$ & $1.00 \pm 0.15$ & $1.00 \pm 0.40$ \\
\hline & $5 \mu \mathrm{M}$ & $0.82 \pm 0.33$ & $3.26 \pm 1.40$ & $0.66 \pm 0.15$ & $18.33 \pm 1.17$ \\
\hline \multirow{2}{*}{ RRTF1 } & $0 \mu \mathrm{M}$ & $1.00 \pm 0.41$ & $1.00 \pm 0.48$ & $1.00 \pm 0.30$ & $1.00 \pm 0.53$ \\
\hline & $5 \mu \mathrm{M}$ & $0.25 \pm 0.07$ & $0.55 \pm 0.14$ & $3.54 \pm 2.25$ & $4.59 \pm 1.11$ \\
\hline \multicolumn{6}{|l|}{ Root } \\
\hline \multirow{2}{*}{ AT1G05340 } & $0 \mu \mathrm{M}$ & $1.00 \pm 0.35$ & $1.00 \pm 0.12$ & $1.00 \pm 0.35$ & $1.00 \pm 0.12$ \\
\hline & $5 \mu \mathrm{M}$ & $1.11 \pm 0.18$ & $1.33 \pm 0.25$ & $0.47 \pm 0.07$ & $1.50 \pm 0.31$ \\
\hline \multirow{2}{*}{ AT1G19020 } & $0 \mu \mathrm{M}$ & $1.00 \pm 0.27$ & $1.00 \pm 0.14$ & $1.00 \pm 0.27$ & $1.00 \pm 0.31$ \\
\hline & $5 \mu \mathrm{M}$ & $2.20 \pm 0.52$ & $1.88 \pm 0.35$ & $0.52 \pm 0.09$ & $3.56 \pm 0.75$ \\
\hline \multirow{2}{*}{ AT1G57630 } & $0 \mu \mathrm{M}$ & $1.00 \pm 0.10$ & $1.00 \pm 0.18$ & $1.00 \pm 0.01$ & $1.00 \pm 0.32$ \\
\hline & $5 \mu \mathrm{M}$ & $1.20 \pm 0.03$ & $1.43 \pm 0.26$ & $0.46 \pm 0.07$ & $2.57 \pm 0.76$ \\
\hline \multirow{2}{*}{ AT2G21640 } & $0 \mu \mathrm{M}$ & $1.00 \pm 0.07$ & $1.00 \pm 0.19$ & $1.00 \pm 0.00$ & $1.00 \pm 0.11$ \\
\hline & $5 \mu \mathrm{M}$ & $1.23 \pm 0.05$ & $0.95 \pm 0.07$ & $0.76 \pm 0.10$ & $1.32 \pm 0.29$ \\
\hline \multirow{2}{*}{ AT2G43510 } & $0 \mu \mathrm{M}$ & $1.00 \pm 0.69$ & $1.00 \pm 0.46$ & $1.00 \pm 0.32$ & $1.00 \pm 0.26$ \\
\hline & $5 \mu \mathrm{M}$ & $0.60 \pm 0.20$ & $0.31 \pm 0.04$ & $0.42 \pm 0.07$ & $2.96 \pm 1.38$ \\
\hline \multirow{2}{*}{ ZAT12 } & $0 \mu \mathrm{M}$ & $1.00 \pm 0.04$ & $1.00 \pm 0.21$ & $1.00 \pm 0.22$ & $1.00 \pm 0.21$ \\
\hline & $5 \mu \mathrm{M}$ & $1.35 \pm 0.43$ & $1.24 \pm 0.31$ & $1.09 \pm 0.14$ & $10.17 \pm 2.24$ \\
\hline \multirow{2}{*}{ RRTF1 } & $0 \mu \mathrm{M}$ & $1.00 \pm 0.11$ & $1.00 \pm 0.46$ & $1.00 \pm 0.69$ & $1.00 \pm 0.43$ \\
\hline & $5 \mu \mathrm{M}$ & $1.27 \pm 0.19$ & $0.64 \pm 0.13$ & $1.20 \pm 0.50$ & $8.58 \pm 0.66$ \\
\hline
\end{tabular}

Although $\mathrm{RBOHC}$ is known to be very low abundant in leaves under control conditions, a strong increase in transcripts was already observed in the leaves after $4 \mathrm{~h}$ of exposure, and a fifty-fold increase was even seen after $24 \mathrm{~h}$ of exposure (Table 4) [44]. The gene expression levels of both RBOHD and $R B O H F$ in the leaves were only significantly elevated after $24 \mathrm{~h}$ of $\mathrm{Cd}$ exposure. Both peaks in the induction of the transcript levels of these ROS-generating enzymes were accompanied by a certain extent of oxidative challenge, as reflected by the higher expression of the oxidative stress hallmark genes [43]. More specifically, after $4 \mathrm{~h}$ of exposure, transcript levels of AT1G05340 and AT1G19020 were increased and coincided with the induction of $R B O H C$ in the leaves (Table 4). After $24 \mathrm{~h}$, oxidative challenge occurred to a larger extent, as reflected by a simultaneous and strong induction of all stress markers and oxidative challenge-related genes (Table 4). 
While Cd-induced oxidative challenge originates from an indirect rise of general ROS levels, our attention was drawn towards $\mathrm{H}_{2} \mathrm{O}_{2}$, which is often put forward as a prominent signalling molecule [28,45]. In both roots and leaves, $\mathrm{H}_{2} \mathrm{O}_{2}$ levels were significantly enhanced at $24 \mathrm{~h}$ of $\mathrm{Cd}$ exposure (Figure 3a), which occurred in parallel with an increase in transcript levels of NADPH oxidases and oxidative stress-related genes (Table 4). As $\mathrm{H}_{2} \mathrm{O}_{2}$ levels are often modulated by GSH, and because free GSH levels fluctuated strongly in our exposure set-up, we considered relative $\mathrm{H}_{2} \mathrm{O}_{2}$ changes in relation to the Cd-induced changes in GSH levels (Figure 3b). This allowed us to obtain an integrative view of the redox status in both organs. The highest ratios were observed in the roots between $2 \mathrm{~h}$ and $6 \mathrm{~h}$ of exposure, with a peak observed after $4 \mathrm{~h}$. Even though still significantly elevated, the ratio seemed to stabilise after $24 \mathrm{~h}$ in the roots. In the leaves, no significant changes were observed (Figure 3b).
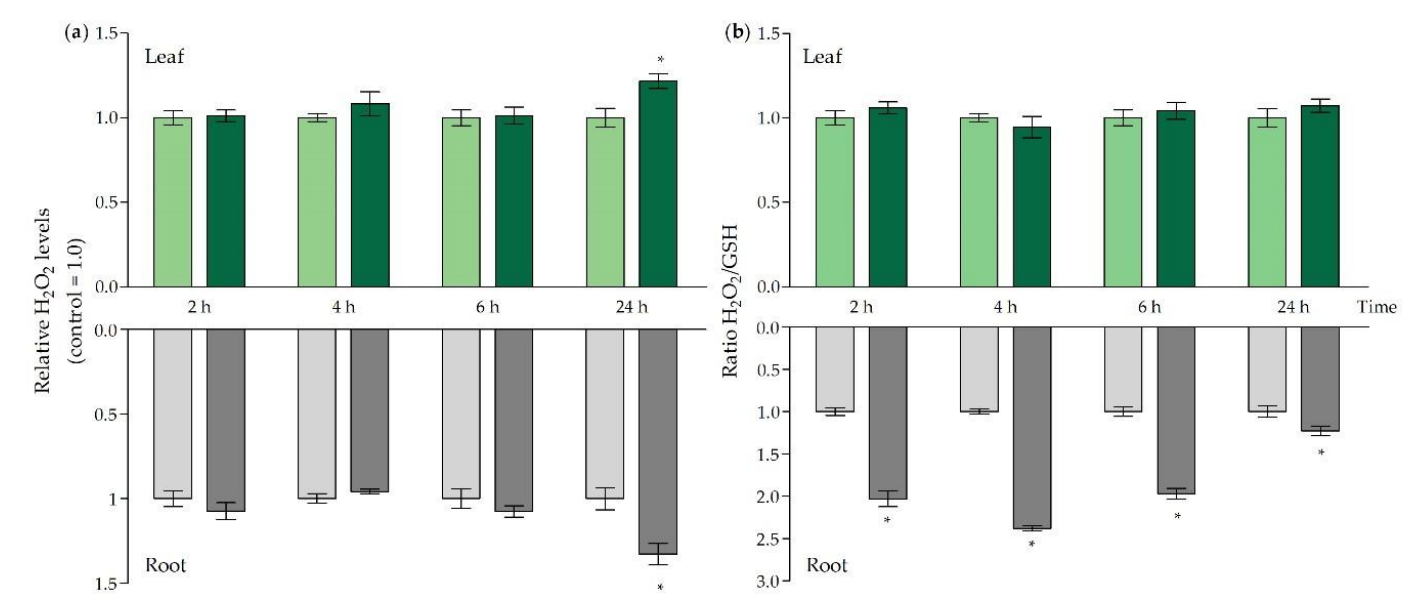

Figure 3. (a) Relative hydrogen peroxide $\left(\mathrm{H}_{2} \mathrm{O}_{2}\right)$ levels and (b) $\mathrm{H}_{2} \mathrm{O}_{2} / \mathrm{GSH}$ ratios in leaves (green bars) and roots (grey bars) of Arabidopsis thaliana plants grown under control conditions $\left(0 \mu \mathrm{M} \mathrm{CdSO}_{4}\right.$, light bars) or exposed to $5 \mu \mathrm{M} \mathrm{CdSO}_{4}$ (dark bars) during $2 \mathrm{~h}, 4 \mathrm{~h}, 6 \mathrm{~h}$ and $24 \mathrm{~h}$ after 3 weeks of growth. For each time point, data represent the mean \pm S.E. of four biological independent replicates. Significant differences ( $t$-test: $p<0.05)$ between control and exposed plants, within each time point, are indicated with an asterisk $\left({ }^{*}\right)$.

\subsection{Ethylene-Related Signalling and Stress Responses}

The stress hormone ethylene is known to be a key regulator of plant responses to metal stress [46]. Its vital role in the responses to Cd stress was already brought forward by Schellingen et al. (2014 and 2015) $[31,35]$. These studies demonstrated that $C d$ exposure stimulates the synthesis of ethylene that, in turn, mediates the Cd-induced responses via, for example, the stimulation of GSH biosynthesis and metabolism [31,35]. In this study, the transcriptional profile of ethylene biosynthesis and responsive genes was considered together with the production of ACC, its direct precursor (Table 5 and Figure 4). The latter, which is the intermediate between SAM and ethylene, is often put forward as a short- and long-distance signalling molecule both dependent and independent of ethylene [47]. In this study, both ACS isoforms were increased at the transcript level under Cd stress in the roots. However, ACS6 was already significantly induced starting from $4 \mathrm{~h}$ of exposure, followed by ACO2 and ACO4 after $6 \mathrm{~h}$, and after $24 \mathrm{~h} A C S 2$ was also significantly higher. All transcripts remained significantly elevated up to $24 \mathrm{~h}$ of exposure (Table 5). Furthermore, the significantly increased expression of ERF1, starting from $6 \mathrm{~h}$, hints towards active ethylene signalling at the root level. This ethylene response established at the transcript level was preceded by the significant induction of MPK3 and MPK6 after $2 \mathrm{~h}$ and OXI1 and WRKY33 after $4 \mathrm{~h}$ (Table 5). The transcription factor WRKY33 acts downstream of the MPK3/6 pathway. 
Table 5. Transcript levels of ethylene-related genes in roots and leaves of Arabidopsis thaliana plants grown under control conditions $\left(0 \mu \mathrm{M} \mathrm{CdSO}_{4}\right)$ or exposed to $5 \mu \mathrm{M} \mathrm{CdSO}_{4}$ during $2 \mathrm{~h}, 4 \mathrm{~h}, 6 \mathrm{~h}$ and $24 \mathrm{~h}$. For each time point, data are given as the mean \pm S.E. of four biological replicates relative to the control set at 1.00. Significant differences ( $t$-test: $p<0.05)$ between control and exposed plants, within each time point, are marked in colour (upregulated: $\square$, downregulated: $\square$ ). ACS: ACC synthase; ACO: ACC oxidase; ERF1: ethylene responsive factor 1; OXI1: oxidative signal inducible 1; MPK: mitogen-activated protein kinase; WRKY33: WRKY DNA-binding protein 33.

\begin{tabular}{|c|c|c|c|c|c|}
\hline \multicolumn{6}{|c|}{ Ethylene-Related Genes } \\
\hline Gene & $\mathrm{CdSO}_{4}$ & $2 \mathrm{~h}$ & $4 \mathrm{~h}$ & $6 \mathrm{~h}$ & $24 \mathrm{~h}$ \\
\hline \multicolumn{6}{|l|}{ Leaf } \\
\hline \multirow{2}{*}{ ACS2 } & $0 \mu \mathrm{M}$ & $1.00 \pm 0.08$ & $1.00 \pm 0.33$ & $1.00 \pm 0.27$ & $1.00 \pm 0.18$ \\
\hline & $5 \mu \mathrm{M}$ & $1.17 \pm 0.56$ & $2.01 \pm 0.82$ & $1.57 \pm 0.21$ & $366.12 \pm 25.94$ \\
\hline \multirow{2}{*}{ ACS6 } & $0 \mu \mathrm{M}$ & $1.00 \pm 0.06$ & $1.00 \pm 0.09$ & $1.00 \pm 0.02$ & $1.00 \pm 0.12$ \\
\hline & $5 \mu \mathrm{M}$ & $0.91 \pm 0.08$ & $2.03 \pm 0.61$ & $3.73 \pm 1.07$ & $9.36 \pm 1.76$ \\
\hline \multirow{2}{*}{ ACO2 } & $0 \mu \mathrm{M}$ & $1.00 \pm 0.08$ & $1.00 \pm 0.08$ & $1.00 \pm 0.23$ & $1.00 \pm 0.10$ \\
\hline & $5 \mu \mathrm{M}$ & $0.74 \pm 0.09$ & $1.08 \pm 0.08$ & $1.00 \pm 0.25$ & $5.48 \pm 0.19$ \\
\hline \multirow{2}{*}{ ACO4 } & $0 \mu \mathrm{M}$ & $1.00 \pm 0.06$ & $1.00 \pm 0.02$ & $1.00 \pm 0.23$ & $1.00 \pm 0.08$ \\
\hline & $5 \mu \mathrm{M}$ & $0.95 \pm 0.22$ & $1.41 \pm 0.05$ & $1.76 \pm 0.44$ & $9.36 \pm 2.24$ \\
\hline \multirow{2}{*}{ ERF1 } & $0 \mu \mathrm{M}$ & $1.00 \pm 0.27$ & $1.00 \pm 0.24$ & $1.00 \pm 0.10$ & $1.00 \pm 0.10$ \\
\hline & $5 \mu \mathrm{M}$ & $0.83 \pm 0.35$ & $2.59 \pm 1.33$ & $9.00 \pm 1.09$ & $142.90 \pm 21.59$ \\
\hline \multirow{2}{*}{ OXI1 } & $0 \mu \mathrm{M}$ & $1.00 \pm 0.35$ & $1.00 \pm 0.41$ & $1.00 \pm 0.27$ & $1.00 \pm 0.51$ \\
\hline & $5 \mu \mathrm{M}$ & $1.07 \pm 0.34$ & $2.07 \pm 0.33$ & $10.66 \pm 1.41$ & $58.15 \pm 18.54$ \\
\hline \multirow{2}{*}{ MPK3 } & $0 \mu \mathrm{M}$ & $1.00 \pm 0.02$ & $1.00 \pm 0.19$ & $1.00 \pm 0.08$ & $1.00 \pm 0.06$ \\
\hline & $5 \mu \mathrm{M}$ & $1.13 \pm 0.13$ & $1.53 \pm 0.38$ & $1.85 \pm 0.13$ & $4.02 \pm 0.43$ \\
\hline \multirow{2}{*}{ MPK6 } & $0 \mu \mathrm{M}$ & $1.00 \pm 0.04$ & $1.00 \pm 0.09$ & $1.00 \pm 0.05$ & $1.00 \pm 0.02$ \\
\hline & $5 \mu \mathrm{M}$ & $1.39 \pm 0.01$ & $1.45 \pm 0.09$ & $1.00 \pm 0.07$ & $2.04 \pm 0.14$ \\
\hline \multirow{2}{*}{ WRKY33 } & $0 \mu \mathrm{M}$ & $1.00 \pm 0.02$ & $1.00 \pm 0.20$ & $1.00 \pm 0.07$ & $1.00 \pm 0.16$ \\
\hline & $5 \mu \mathrm{M}$ & $1.30 \pm 0.27$ & $2.65 \pm 0.78$ & $3.87 \pm 1.43$ & $13.43 \pm 0.93$ \\
\hline \multicolumn{6}{|l|}{ Root } \\
\hline \multirow{2}{*}{ ACS2 } & $0 \mu \mathrm{M}$ & $1.00 \pm 0.12$ & $1.00 \pm 0.07$ & $1.00 \pm 0.22$ & $1.00 \pm 0.11$ \\
\hline & $5 \mu \mathrm{M}$ & $1.13 \pm 0.11$ & $0.78 \pm 0.11$ & $0.75 \pm 0.08$ & $3.76 \pm 1.22$ \\
\hline \multirow{2}{*}{ ACS6 } & $0 \mu \mathrm{M}$ & $1.00 \pm 0.02$ & $1.00 \pm 0.07$ & $1.00 \pm 0.14$ & $1.00 \pm 0.09$ \\
\hline & $5 \mu \mathrm{M}$ & $1.61 \pm 0.16$ & $1.72 \pm 0.17$ & $1.60 \pm 0.17$ & $5.25 \pm 1.83$ \\
\hline \multirow{2}{*}{ ACO2 } & $0 \mu \mathrm{M}$ & $1.00 \pm 0.21$ & $1.00 \pm 0.13$ & $1.00 \pm 0.09$ & $1.00 \pm 0.31$ \\
\hline & $5 \mu \mathrm{M}$ & $1.11 \pm 0.17$ & $1.15 \pm 0.07$ & $2.23 \pm 0.11$ & $5.05 \pm 0.34$ \\
\hline \multirow{2}{*}{ ACO4 } & $0 \mu \mathrm{M}$ & $1.00 \pm 0.17$ & $1.00 \pm 0.11$ & $1.00 \pm 0.15$ & $1.00 \pm 0.11$ \\
\hline & $5 \mu \mathrm{M}$ & $1.18 \pm 0.10$ & $1.51 \pm 0.14$ & $1.95 \pm 0.12$ & $7.39 \pm 1.23$ \\
\hline \multirow{2}{*}{ ERF1 } & $0 \mu \mathrm{M}$ & $1.00 \pm 0.37$ & $1.00 \pm 0.33$ & $1.00 \pm 0.17$ & $1.00 \pm 0.02$ \\
\hline & $5 \mu \mathrm{M}$ & $1.27 \pm 0.13$ & $1.39 \pm 0.20$ & $3.01 \pm 0.50$ & $22.01 \pm 2.75$ \\
\hline \multirow{2}{*}{ OXI1 } & $0 \mu \mathrm{M}$ & $1.00 \pm 0.08$ & $1.00 \pm 0.07$ & $1.00 \pm 0.12$ & $1.00 \pm 0.14$ \\
\hline & $5 \mu \mathrm{M}$ & $1.27 \pm 0.13$ & $1.70 \pm 0.11$ & $1.22 \pm 0.10$ & $1.20 \pm 0.37$ \\
\hline \multirow{2}{*}{ МРКЗ } & $0 \mu \mathrm{M}$ & $1.00 \pm 0.12$ & $1.00 \pm 0.02$ & $1.00 \pm 0.07$ & $1.00 \pm 0.12$ \\
\hline & $5 \mu \mathrm{M}$ & $1.68 \pm 0.18$ & $1.51 \pm 0.10$ & $1.31 \pm 0.07$ & $2.89 \pm 0.36$ \\
\hline \multirow{2}{*}{ MPK6 } & $0 \mu \mathrm{M}$ & $1.00 \pm 0.14$ & $1.00 \pm 0.06$ & $1.00 \pm 0.07$ & $1.00 \pm 0.02$ \\
\hline & $5 \mu \mathrm{M}$ & $1.63 \pm 0.13$ & $1.11 \pm 0.02$ & $2.93 \pm 0.26$ & $2.36 \pm 0.21$ \\
\hline \multirow{2}{*}{ WRKY33 } & $0 \mu \mathrm{M}$ & $1.00 \pm 0.30$ & $1.00 \pm 0.09$ & $1.00 \pm 0.23$ & $1.00 \pm 0.16$ \\
\hline & $5 \mu \mathrm{M}$ & $1.15 \pm 0.09$ & $1.93 \pm 0.02$ & $0.97 \pm 0.04$ & $1.74 \pm 0.44$ \\
\hline
\end{tabular}




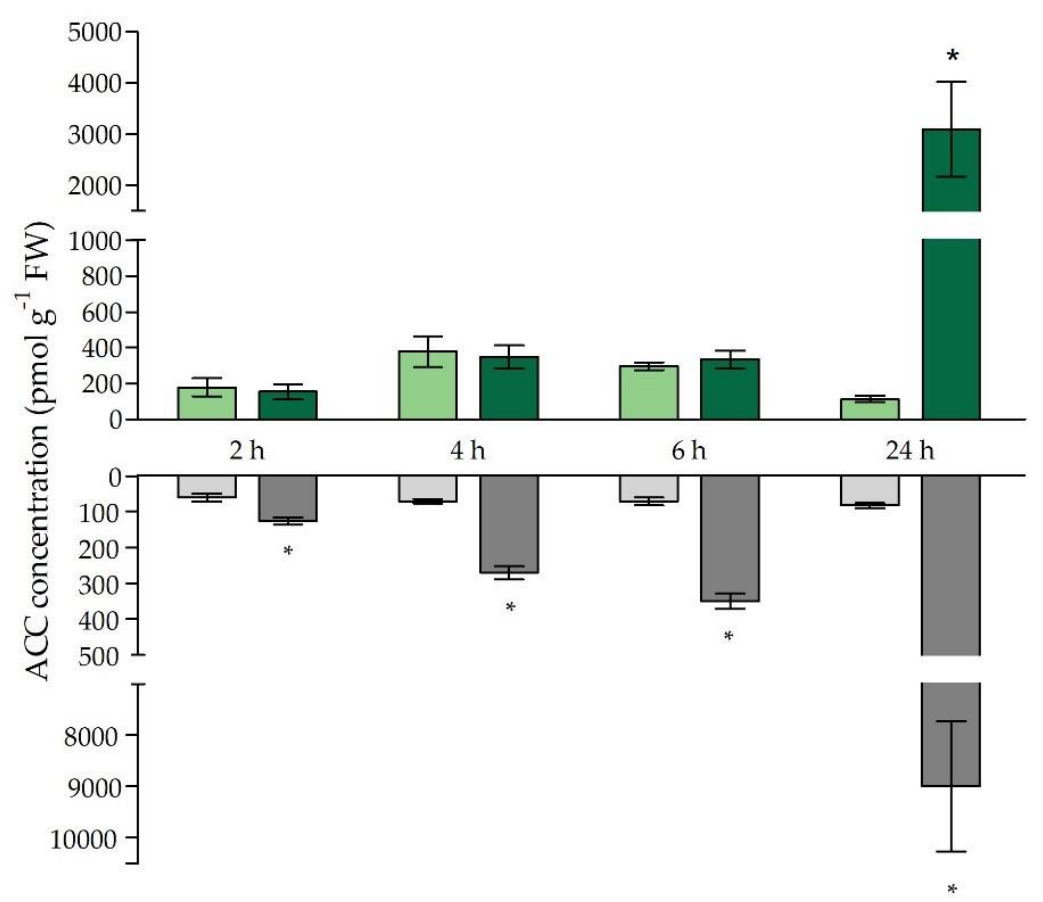

Figure 4. Free 1-aminocyclopropane-1-carboxylic acid (ACC) concentrations (pmol g ${ }^{-1}$ fresh weight) in leaves (green bars) and roots (grey bars) of Arabidopsis thaliana plants grown under control conditions $\left(0 \mu \mathrm{M} \mathrm{CdSO}_{4}\right.$, light bars) or exposed to $5 \mu \mathrm{M} \mathrm{CdSO}_{4}$ (dark bars) during $2 \mathrm{~h}, 4 \mathrm{~h}, 6 \mathrm{~h}$ and $24 \mathrm{~h}$ after 3 weeks of growth. For each time point, data represent the mean \pm S.E. of four biological independent replicates. Significant differences ( $t$-test: $p<0.05)$ between control and exposed plants, within each time point, are indicated with an asterisk $\left(^{*}\right)$.

Similarly, in the leaves of Cd-exposed plants, ERF1 was also significantly increased after $6 \mathrm{~h}$ and $24 \mathrm{~h}$ and coincided with an increase in OXI1 transcripts, which was preceded by a significant upregulation of MPK6 (Table 5).

Considering the ethylene biosynthesis-related genes, overall strong and significant increases were observed after $24 \mathrm{~h}$ of exposure for all genes considered (Table 5). Concerning free ACC concentrations, responses strongly differed between roots and leaves. In roots, free ACC concentrations were already significantly elevated compared to the control levels starting from $2 \mathrm{~h}$ of $\mathrm{Cd}$ exposure and further increased towards $24 \mathrm{~h}$ (Figure 4). A delayed response was observed for the leaves as non-conjugated ACC levels were only significantly increased after $24 \mathrm{~h}$ of exposure, albeit to a very large extent (Figure 4).

\section{Discussion}

Plants possess a great plasticity and adaptive potential, enabling them to cope with a broad range of environmental stresses and acclimate to changing environments. The process of acclimation encompasses homeostatic adjustments and results in newly established equilibria [48,49]. However, acclimation is typically preceded by a stress response, which generally occurs within a time frame of seconds to days, and most often leads to a temporary suboptimal performance [48]. The study of acute responses to $\mathrm{Cd}$ exposure, within the period of $0 \mathrm{~h}$ to $24 \mathrm{~h}$, allows us to identify the pressure points of $\mathrm{Cd}$ stress before new equilibria are reached. Knowledge concerning such pressure points and acute responses is required to improve our understanding of the triggers and sequence of events that precede acclimation. The obtained knowledge can contribute to the improvement of plant acclimation, enabling plants to reach their full capacity even under stressful conditions. This trait is highly required in the current conditions, since non-polluted arable land is becoming sparse. 
While the dual role of GSH under Cd stress, as a chelator and anti-oxidant, was already touched upon by Jozefczak et al. (2014), our data further underline the dilemmas plants encounter in their acute responses to environmentally realistic, sublethal (i.e., $5 \mu \mathrm{M}$ ) Cd stress [10,41]. More specifically, the present study further uncovers the Cd-induced trade-offs between (1) GSH as a chelator and anti-oxidative metabolite and (2) ROS signalling and oxidative stress, i.e., an oxidative challenge. From our data, it became clear that these trade-offs were mainly manifested at the root level, especially with regard to GSH, that became strongly depleted within $2 \mathrm{~h}$ of $\mathrm{Cd}$ exposure (Figure 2). Jozefczak et al. (2014) indicated that this depletion occurred due to the allocation of GSH to its Cd-chelating oligomers, namely phytochelatins [10]. The fact that, in the present study, GSH levels were even more strongly depleted after $4 \mathrm{~h}$ adds to our knowledge that the effect on free GSH levels becomes more pronounced and persists at least until $4 \mathrm{~h}$ after exposure (Figure 2). Overall, the Cd-induced changes in root GSH concentrations fit the typical stress response curve described by Lambers et al. (1998) [48]. First of all, the initial alarming phase becomes visible by the rapid depletion of GSH followed by the restitution phase, which is established between $6 \mathrm{~h}$ and $24 \mathrm{~h}$, as a full recovery to control levels occurred within this time frame (Figure 2). As shown previously, overcompensation by increased GSH levels does not occur at the root level under $5 \mu \mathrm{M}$ of $\mathrm{Cd}$, at least not after $24 \mathrm{~h}, 48 \mathrm{~h}$ and $72 \mathrm{~h} \mathrm{[10].} \mathrm{At} \mathrm{the} \mathrm{leaf} \mathrm{level,}$ even though $\mathrm{Cd}$ was translocated early on and the leaf $\mathrm{Cd}$ concentrations were significantly elevated from $2 \mathrm{~h}$ onwards (Table 1), no changes in GSH concentrations were observed within the considered $24 \mathrm{~h}$ time frame (Figure 2). However, it is known that leaf GSH levels significantly increase after $48 \mathrm{~h}$ and $72 \mathrm{~h}$ of exposure to $5 \mu \mathrm{M} \mathrm{Cd}$ [31]. As reviewed by Tausz et al. (2004) and Zagorchev et al. (2013), an increase in GSH concentrations is often observed as an acclimatory response to a range of stresses and hints towards a better stress resistance and a new steady-state $[49,50]$. Note, however, that increased GSH levels, exogenously applied or transgenically enhanced, do not necessarily imply an improved tolerance, especially in the case of Cd stress [51,52]. The fact that the manipulation of GSH levels can lead to increased $\mathrm{Cd}$ sensitivity underlines the fine-tuning that is required for proper acclimation and emphasizes the importance of the alarming phase, provoked by the rapid and strong GSH depletion at the root level (Figure 2). Moreover, our data indicate that the depletion and recovery of GSH levels have a relatively fast nature, which further confirms the fact that the pressure points of stress factors are often overlooked when considering longer exposure time frames and underlines the importance of monitoring stresses at different time points. In addition, the fact that responses strongly differ between roots and leaves points out that at least both organs need to be considered when studying plant stress responses and acclimation, especially when the stress is (partly) propagated via the root system.

Even though several studies have indicated that a rapid and transient depletion of GSH occurs after exposure to excess metal concentrations, little is known about the impact of this event on the plant's responses $[10,53,54]$. Indeed, depletion of this prominent anti-oxidant could lead to an oxidative challenge at the root level as its anti-oxidative capacity is largely impaired. However, the extent to which this event is detrimental or, on the contrary, contributes to stress signalling-and, ultimately, plant acclimation-remains unclear. Alterations of the GSH pool and generation of the prominent ROS signalling molecule $\mathrm{H}_{2} \mathrm{O}_{2}$ are both central components of stress-induced signal transduction and often act in concert $[29,45]$. The ratio between oxidising $\mathrm{H}_{2} \mathrm{O}_{2}$ and the important anti-oxidant $\mathrm{GSH}$ allows us to obtain an integrative view of the Cd-induced redox changes and shows that $\mathrm{H}_{2} \mathrm{O}_{2}$ levels in the roots are most strongly elevated in relation to GSH early on (Figure 3b). Previous studies have indicated that the changes in GSH status are rather a modulator of the stress-induced increases in $\mathrm{H}_{2} \mathrm{O}_{2}$ than merely a passive result $[29,30]$. In our study, the $\mathrm{Cd}$-induced $\mathrm{H}_{2} \mathrm{O}_{2}$ increases are modulated by the depletion of the GSH pool and are not influenced by changes in its redox state, because the redox state of the GSH pool was not affected by Cd exposure and the percentage of reduced GSH remained tightly controlled above $90 \%$ (Table S3). Consistent with these findings, it was shown by Schnaubelt et al. (2015) that buthionine sulfoximine (BSO)-induced depletion of the root GSH level did not necessarily impact its redox state [30]. Moreover, lowered GSH levels counteract its oxidation [29]. As GR is key in the recycling of the oxidised GSSG back to its reduced form, an increased GR activity may explain 
this tight control. However, in our study, GR activity in the roots was only significantly increased after $24 \mathrm{~h}$ of exposure (Table 3). Therefore, it can be concluded that its activity is not contributing to maintain a reduced GSH pool at the early time points when GSH becomes depleted (Figure 2). As shown by several studies, GSH1 and GSH2 are typically induced upon Cd exposure [9,10,55-57]. In our study, their transcriptional induction coincided with the restoration of GSH levels observed after $6 \mathrm{~h}$ and $24 \mathrm{~h}$ at the root level (Figure 2). The catalyser of the first and rate-limiting step of GSH biosynthesis, GSH1, is regulated at several levels. For example, GSH itself is known to have a negative impact on its own production by inhibition of GSH1 activity [57]. Hence, the GSH-depleted conditions (Figure 2) in our study favour an increased activity of GSH1 in the roots. Moreover, at the transcript level, the transcription factor ZAT6 is known to stimulate GSH1 transcription and its own expression is enhanced upon Cd exposure, which was also observed in our study [56]. In general, this study is in agreement with the conclusion drawn by Han et al. (2013) that the plant cell redox status is configured in such a way that depletion inhibits GSH oxidation and strong changes in GSH concentration are sufficient to alter the cell's redox potential and drive GSH accumulation [29].

It is clear that intracellular GSH is a major modulator of stress responses and the acclimation process thereafter. Noteworthy, however, is the eGSH residing in the apoplastic space, which is largely regulated by the $\gamma$-glutamyl cycle $[24,25]$. The fine-tuning of the apoplastic GSH content by this cycle serves in redox, balancing the apoplastic space and recovery of GSH—or, more precisely, its constituent amino acids-into the cell. The driving force of eGSH degradation is the apoplastic GGT enzyme encoded by GGT1, which catalyses the transfer of the $\gamma$-glutamyl group of GSH to a range of acceptors like water or another amino acid [24]. Considering there is no mechanism to reduce extracellular GSSG, this enzyme prevents the accumulation of GSSG in the apoplastic space, mitigating oxidative stress [24]. Even though GGT1 is most strongly expressed in the leaves of $A$. thaliana, our data show that the Cd-induced GGT1 upregulation is more pronounced and occurs faster in the root system (Table 2) [25]. Accordingly, enzyme-histochemical analyses showed that GGT activity was very intense in root tips of Hordeum vulgare and Zea mays [26,58]. Furthermore, Uzilday et al. (2018) observed a strong induction of GGT1 under endoplasmic reticulum stress, a stress that is also known to be evoked by short-term $\mathrm{Cd}$ exposure $[59,60]$. It has been suggested that the $\gamma$-glutamyl cycle serves to link the environment to the plant cell and may provide a way to transfer redox information between the apoplast and the symplast [20]. Other key components known to be involved in the apoplastic redox regulation that bridge the extracellular and intracellular space are NADPH oxidases. In our study, a similar transcriptional profile was observed for $R B O H C, D$ and $F$, which coincided with GGT1 expression (Tables 2 and 3). The Cd-induced transcription of these prominent NADPH oxidase isoforms (Table 3) hints at an increased production of superoxide and subsequently $\mathrm{H}_{2} \mathrm{O}_{2}$ in the roots. An augmented $\mathrm{H}_{2} \mathrm{O}_{2}$ production, as observed in our study (Figure 3), could lead to oxidation of the apoplastic GSH pool and activation of the $\gamma$-glutamyl cycle. In summary, these data point towards a redox-related signalling event that is in full practice upon $2 \mathrm{~h}$ of $\mathrm{Cd}$ exposure and persists at least up to $24 \mathrm{~h}$ of exposure. Furthermore, as shown by Tolin et al. (2013), apoplastic GGT is an important modulator of the redox response, since the knockout of GGT1 leads to a constitutive "alert response" even in absence of environmental stimuli $[20,21]$. Therefore, it can be suggested that GGT encoded by GGT1 also functions as an important modulator in the redox sensing and signalling under $\mathrm{Cd}$ stress.

In our study, only a small subset of oxidative stress markers was transcriptionally induced in the root, and only after $24 \mathrm{~h}$ of exposure (Table 4) [43]. This is in line with our suggestion that the early alterations observed in the $\mathrm{H}_{2} \mathrm{O}_{2} / G S H$ at the root level are required for a proper signalling response under $\mathrm{Cd}$ stress, rather than having merely a detrimental oxidative stress effect. In addition, the fact that the transcriptional profile indicating oxidative stress markers in the roots was only induced to a limited extent and delayed, is in line with the findings of Schnaubelt et al. (2015). They suggested that GSH depletion evokes a very specific response as the transcriptome of the root meristemless 1-1 (rml1-1) mutant, harbouring only $2.7 \%$ of WT GSH levels. This response is different from that of the catalase 2 (cat2-1) mutant and lacks an induction of the oxidative stress markers, which might 
be explained by the absence of a change in the GSH/GSSG ratio [30]. Another important modulator of ROS signalling is the transcription factor RRTF1 that was transcriptionally induced in both roots and leaves but only upon $24 \mathrm{~h}$ (Table 4). Matsuo et al. (2015) demonstrated that the expression of RRTF1 is stimulated by ROS and that RRTF1 itself is responsible for the amplification of ROS generated by a stressor that perturbs basal ROS levels [61]. Additionally, one of its target genes, ZAT12, also became significantly upregulated upon $24 \mathrm{~h}$ of Cd exposure (Table 4), which in its turn stimulates the transcription of, for example, $R B O H D$, that was increased after $24 \mathrm{~h}$ as well (Table 3) [61]. Both are implemented in the regulation of ROS signalling under unfavourable conditions, and in this case their upregulation indicates ROS amplification to possibly intensify responses after $24 \mathrm{~h}$ when root GSH levels are stabilised. Indeed, at this time point $\mathrm{H}_{2} \mathrm{O}_{2}$ levels were significantly increased in both root and leaves independently of GSH (Figure 3a). In this way, the Cd-induced signalling responses might be redirected away from GSH-dependent redox sensing, as root GSH levels are restored to control levels at this later time point (Figure 2) and can no longer serve as a redox signal.

Our data indicate that the GSH-related leaf responses are delayed and less pronounced in comparison to the roots (Figure 2 and Table 2). This is plausible, since the roots are in direct contact with the $\mathrm{Cd}$-containing nutrient solution. However, our data show that $\mathrm{Cd}$ is translocated early on to the aerial parts, leading to significantly higher $\mathrm{Cd}$ concentrations in the leaves compared to the control already after $2 \mathrm{~h}$ of exposure (Table 1). Nevertheless, no GSH depletion was observed in the leaves (Figure 2). As mentioned before, Cd-induced GSH depletion is caused by the allocation of GSH to PC synthesis, a process that is also known to occur in leaves after $24 \mathrm{~h}$ of exposure to $5 \mu \mathrm{M} \mathrm{Cd}$ [10]. Hence, since leaf GSH levels are not negatively affected (Figure 2), leaf signalling responses possibly directly shift to the GSH-independent signalling response, as described above. Our data indicate that Cd-induced leaf GSH stimulation serves to buffer the impact of stresses at the leaf level and that GSH fulfils a protective role rather than a signalling role. This implies, however, that other components are responsible for stress signalling in the leaves in order to reach acclimation.

It is clear from our study that the early depletion in root GSH levels does not stand alone. More specifically, the production of the ethylene precursor and important signalling molecule ACC was already significantly higher from $2 \mathrm{~h}$ of exposure onwards at the root level (Figure 4). As demonstrated by Schellingen et al. (2015), ROS signalling is integrated into the signalling cascade that precedes Cd-induced ethylene biosynthesis by increasing OXI1 expression, which, in its turn, activates MPK3 and MPK6 [31,38]. These kinases target ACS2 and ACS6, leading to an increase in their half-life and a stimulation of their gene expression [62-64]. In our study, both MPK3 and MPK6 seem to function early in the root responses to Cd stress, and their transcriptional induction (Table 5) collides with the higher root ACC concentrations (Figure 4). Moreover, it is known that, in A. thaliana, OXI1 gene expression and kinase activity are induced upon exposure to a broad range of $\mathrm{H}_{2} \mathrm{O}_{2}$-generating stimuli [38]. One such stimulus could, for example, originate from RBOHC, and indeed the knockout of $\mathrm{RBOHC}$ leads to a decreased induction of OXI1 in the roots of $A$. thaliana [44]. Correspondingly, in our study, the induction of OXI1 (Table 5) peaks in concert with the highest $\mathrm{H}_{2} \mathrm{O}_{2} / \mathrm{GSH}$ ratio observed in the roots (Figure $3 \mathrm{~b}$ ) and possibly leads to the activation of the aforementioned signalling cascade, with the transcriptional induction of ACS2 and ACS6 as an end result (Table 4). The fact that the ACC concentration (Figure 4) in the roots was already significantly higher after $2 \mathrm{~h}$ of exposure, and therefore preceded the transcriptional induction of ACS2 and ACS6 (Table 4), suggests a rapid activation at the protein level, which later on is extended to the transcript level.

Additionally, ethylene and GSH are strongly intertwined in the responses to Cd stress. It was shown by Schellingen et al. (2015) that leaf GSH stimulation under Cd stress depends on ethylene signalling [31]. More precisely, the considered ethylene insensitive ein2-1 mutants proved unable to increase their leaf GSH levels upon Cd exposure. This also became apparent at the transcript level, as the induction of the GSH metabolism genes was abolished in these mutants [31]. It is clear from our point of view that, at least at the transcript level, ethylene signalling (Table 4) precedes the induction of GSH1, GSH2 and GR1 in the leaves (Table 2). It should be noted, however, that leaf ethylene signalling, 
assessed by the induction of ethylene-responsive genes such as ERF1 (Table 5), precedes the higher leaf ACC concentrations observed after $24 \mathrm{~h}$ of Cd exposure (Figure 4). Therefore, we suggest that the transcriptional induction of ERF1 is not a result of a de novo ethylene synthesis originating from the leaf, but of ethylene produced at the root level that evokes responses in the leaves. However, cross-talk with other phytohormones, like jasmonate, should not be neglected. Nevertheless, studies found that stress-induced ERF1 expression was strongly diminished in the leaves of the ethylene biosynthesis double mutant acs2-6, which further corroborates that ethylene is largely responsible for the induction of ERF1 in the leaves [35,63]. Indeed, at the level of the root, ethylene synthesis, or at least ACC concentration (Figure 4), was already significantly increased upon $2 \mathrm{~h}$ of exposure. Therefore, the root system might serve as a command centre and delivers stress-related signals, like ethylene, to the leaves. The latter will engage in an optimal response that becomes apparent by the stimulation in leaf GSH biosynthesis rather than GSH depletion, which occurs in the roots after similar Cd concentrations are encountered (Figure 2).

\section{Materials and Methods}

\subsection{Plant Culture, Cadmium Treatment and Sampling}

Seeds of wild-type Arabidopsis thaliana plants (Columbia background) were surface-sterilised and incubated in the dark for 3 nights at $4{ }^{\circ} \mathrm{C}$. Seedlings were grown in a hydroponic culture system using purified sand as a substrate and a modified Hoagland nutrient solution [40,41]. Growth conditions were set at $65 \%$ relative humidity under a photoperiod of $12 \mathrm{~h}$ with day/night temperatures of $22{ }^{\circ} \mathrm{C}$ and $18^{\circ} \mathrm{C}$, respectively. The photosynthetically active radiation of sunlight was simulated by providing a combination of blue, red and far-red light (Philips Green-Power LED modules) with a photosynthetic photon flux density of $170 \mu \mathrm{mol} \mathrm{m}{ }^{-2} \mathrm{~s}^{-1}$ at the rosette level. After 3 weeks of growth, wild-type plants were exposed to 0 (control) or $5 \mu \mathrm{M} \mathrm{Cd}$ via addition of $\mathrm{CdSO}_{4}$ to the nutrient solution. Plants were harvested at different points $(0 \mathrm{~h}, 2 \mathrm{~h}, 4 \mathrm{~h}, 6 \mathrm{~h}$ and $24 \mathrm{~h})$ after the start of exposure. Root and rosette fresh weight were determined and samples were snap frozen in liquid nitrogen and stored at $-70{ }^{\circ} \mathrm{C}$ unless stated otherwise.

\subsection{Quantification of Root and Rosette Cd Concentrations}

Harvested leaves were rinsed with distilled water to remove any residual metals. Roots were submerged for $15 \mathrm{~min}$ in $10 \mathrm{mM} \mathrm{Pb}\left(\mathrm{NO}_{3}\right)_{2}$ at $4{ }^{\circ} \mathrm{C}$, to exchange surface-bound metals, and rinsed in distilled water. Prior to analysis, samples were oven-dried at $80^{\circ} \mathrm{C}$ and digested in $\mathrm{HNO} 3(70-71 \%)$ and $\mathrm{HCl}(37 \%)$. Cadmium concentrations were determined via inductive coupled plasma-optical emission spectrometry (ICP-OES; Agilent Technologies 700 Series, Santa Clara, CA, USA). For reference purposes, blank $\left(\mathrm{HNO}_{3}\right)$ and standard (trace elements in spinach, 1570a, Standard Reference Material) samples were included.

\subsection{Gene Expression Analysis}

In order to study Cd-induced responses at the transcriptional level, gene expression analysis was carried out. Root and leaf samples were disrupted under frozen conditions by shredding using two stainless steel beads and the Retsch Mixer Mill MM400 (Retsch, Haan, Germany). Isolation of RNA from the disrupted sample tissue was conducted using the RNAqueous ${ }^{\circledR}$ Kit (Thermo Fisher Scientific, Waltham, MA, USA) according to the manufacturer's instructions. By use of the Nanodrop ${ }^{\circledR}$ ND-1000 Spectrophotometer (Thermo Fisher Scientific), RNA purity and concentration were spectrophotometrically determined. Finally, RNA integrity was analysed using gel electrophoresis, and samples were stored at $-70^{\circ} \mathrm{C}$. After RNA isolation, cDNA was synthesised from equal RNA inputs $(1 \mu \mathrm{g})$ via reverse transcription using the Primescript ${ }^{\mathrm{TM}}$ RT reagent Kit (Takara Bio Inc., Kusatsu, Japan). To remove residual genomic DNA, the RNA samples $(1 \mu \mathrm{g})$ were pre-treated with DNase using 
the TURBO DNA-free ${ }^{\mathrm{TM}} \mathrm{Kit}$ (Ambion). Prior to storage at $-20^{\circ} \mathrm{C}$, the cDNA was ten-fold diluted using a 1/10 Tris-EDTA buffer ( $1 \mathrm{mM}$ Tris- $\mathrm{HCl}, 0.1 \mathrm{mM} \mathrm{Na}_{2}$-EDTA, $\mathrm{pH}$ 8.0).

Using quantitative real-time PCR (qPCR), the expression levels of the genes of interest (GOIs; Table S2) were determined. Reactions were carried out in a 96-well plate with the 7500 Fast Real-Time PCR System (Applied Biosystems, Thermo Fisher Scientific, Foster City, CA, USA) using the Fast SYBR ${ }^{\circledR}$ Green Master Mix (Applied Biosystems, Thermo Fisher Scientific) according to the manufacturer's protocol. Amplification was performed under universal cycling conditions $\left(20 \mathrm{~s} 95^{\circ} \mathrm{C}, 40\right.$ cycles of $3 \mathrm{~s}$ at $95^{\circ} \mathrm{C}$ and $30 \mathrm{~s}$ at $60^{\circ} \mathrm{C}$ ), followed by the generation of a dissociation curve to verify amplicon specificity. The reactions contained $2 \mu \mathrm{L}$ of the diluted cDNA template (or RNase-free $\mathrm{H}_{2} \mathrm{O}$ for the "no template controls"), $5 \mu \mathrm{L} 2 \times$ Fast SYBR ${ }^{\circledR}$ Green Master Mix (Applied Biosystems, Thermo Fisher Scientific) and forward and reverse primers ( $300 \mathrm{nM}$ each, unless mentioned otherwise in Table S1), in a total volume of $10 \mu \mathrm{L}$. Based on the obtained Cq values, the relative gene expression level of the GOIs was determined using the $2^{-\Delta \mathrm{Cq}}$ method. Technical variation was corrected for by normalisation with the geometric average of at least three reference genes (Table S3) that were selected from 10 candidate reference genes based on the GrayNorm Algorithm [65]. Gene-specific forward and reverse primers were designed and optimised via the Primer3 software. Primer specificity was verified in silico using Blast (http://www.arabidopsis.org/Blast/index.jsp). In order to guarantee an optimal reaction efficiency, primer efficiency (E) was evaluated on a standard curve using a two-fold dilution series of a pooled sample and verified to be between $90 \%$ and $110 \%$. All gene annotations, primer sequences and primer efficiencies are shown in supplemental Tables S2 and S3. The qPCR parameters according to the Minimum Information for publication of qPCR Experiments (MIQE) guidelines are shown in supplemental Table S4 [66].

\subsection{Glutathione Concentration}

Both oxidised and reduced GSH were spectrophotometrically determined in root and leaf samples according to the plate reader method described by Queval and Noctor (2007) and modified by Jozefczak et al. (2014) [10,67]. Additionally, minor modifications were carried out concerning the extraction method. Frozen samples $(75 \mathrm{mg})$ were ground using two stainless steel beads and the Retsch Mixer Mill MM400 (Retsch). Samples were further homogenised by adding $200 \mathrm{mM} \mathrm{HCl}$ (6.66 mL mg ${ }^{-1}$ leaf fresh weight; $9.4 \mathrm{~mL} \mathrm{mg}^{-1}$ root fresh weight) and vortexing. After centrifugation (10 $\mathrm{min}, 16,000 \times \mathrm{g}, 4^{\circ} \mathrm{C}$ ), the $\mathrm{pH}$ of the samples was adjusted to 4.5 using $200 \mathrm{mM} \mathrm{NaOH}$, and the samples were kept at $4{ }^{\circ} \mathrm{C}$ throughout the procedure. The assay relied on the GSH-dependent reduction of 5,5-dithiobis (2-nitro-benzoic acid) (DTNB, $600 \mu \mathrm{M}$ ), which was monitored at $412 \mathrm{~nm}$ in a FLUOstar Omega microplate reader (BMG Labtech, Ortenberg, Germany). Formed GSSG or GSSG present in the sample was reduced by glutathione reductase $\left(1 \mathrm{U} \mathrm{mL}^{-1}\right)$ in the presence of NADPH $(500 \mathrm{mM})$. The absorbance rate over time was proportional to the GSH concentration in the samples, which was determined using a GSH standard curve. In order to measure GSSG, GSH was first complexed by incubating the samples with 1\% 2-vinylpyridine (2-VP) (30 min, room temperature). Complexed GSH and 2-VP were removed by centrifuging the samples twice (10 $\left.\mathrm{min}, 16,000 \times g, 4{ }^{\circ} \mathrm{C}\right)$ prior to the measurement.

\subsection{Hydrogen Peroxide Measurements}

Relative hydrogen peroxide $\left(\mathrm{H}_{2} \mathrm{O}_{2}\right)$ concentrations were determined in roots and leaves using the Amplex ${ }^{\mathrm{TM}}$ Red Hydrogen Peroxide/Peroxidase Assay Kit (Invitrogen, Thermo Fisher Scientific, Carlsbad, CA, USA). Frozen samples were disrupted using two stainless steel beads in the Retsch Mixer Mill MM 400 (Retsch). The extraction was carried out in $500 \mu \mathrm{L} 1 \times$ Reaction Buffer, and the samples were shaken continuously at room temperature for $30 \mathrm{~min}$ and centrifuged at $12,000 \times g$ for $5 \mathrm{~min}$. Reactions were performed in a 96-well plate with each well containing $95 \mu \mathrm{L}$ of a working solution consisting of $100 \mu \mathrm{M}$ Amplex ${ }^{\mathrm{TM}}$ Red and $0.2 \mathrm{U} / \mathrm{mL}$ horseradish peroxidase, to which $5 \mu \mathrm{L}$ supernatant was added. After $30 \mathrm{~min}$ incubation in the dark at $30^{\circ} \mathrm{C}$, the samples were excited at 
$560 \mathrm{~nm}$, and resorufin fluorescence was measured at $590 \mathrm{~nm}$ in a FLUOstar Omega microplate reader (BMG Labtech, Ortenberg, Germany).

\subsection{Determination of Free ACC Content}

Frozen root and leaf $(200 \mathrm{mg})$ samples were disrupted using the Retsch Mixer Mill MM 400 (Retsch) and two stainless steel beads. To allow for quantification, $\left[{ }^{2} \mathrm{H}_{4}\right]$ ACC ( $200 \mathrm{pmol}$, Sigma, St. Louis, MO, USA) was added as an internal standard. After centrifugation $\left(20,817 \times g, 15 \mathrm{~min}, 4^{\circ} \mathrm{C}\right.$, Eppendorf 5810R, Hamburg, Germany), ACC was extracted using the solid-phase extraction procedure described by Smets et al. (2003) [68]. Samples were derivatised with pentafluorobenzyl (PFB) bromide (Sigma, Saint Louis, MO, USA) and analysed as PFB-bis-ACC by Negative Ion Chemical Ionisation Gas chromatography-mass spectrometry (NICI GC-MS; Quattro micro MS/MS, Waters; electron energy $70 \mathrm{eV}$, emission $200 \mu \mathrm{A}$, extraction $10 \mathrm{~V}$, source $206 \mu \mathrm{A}$, GC interface T: $120^{\circ} \mathrm{C}$, CI gas flow $69 \mathrm{~mL} / \mathrm{min}$ ). The GC (WCOT) column was purchased from Varian (CP-Sil 5 C8 Low bleed/MS column, $30 \mathrm{~m}$, $250 \mu \mathrm{m}$, film thickness $0.25 \mu \mathrm{m}$ ) using helium as the mobile phase ( $\mathrm{T}$ gradient $50{ }^{\circ} \mathrm{C}$ to $250{ }^{\circ} \mathrm{C}$ at $25{ }^{\circ} \mathrm{C} / \mathrm{min}$ ). Corresponding to their pentafluorobenzyl (PFBbis-ACC) derivatives, the following diagnostic transitions were used for Multiple Reaction Monitoring (MRM): $280>112$ and $280>167$ for ACC and $284>116$ and $284>167$ for $\mathrm{D}_{4}$-ACC. Based on the transitions, $280>112$ and $284>116$ concentrations were calculated.

\subsection{Glutathione Reductase Activity Measurements}

Root and leaf samples $(150 \mathrm{mg}$ ) were homogenised under frozen conditions in a $1 \mathrm{~mL}$ ice-cold $0.1 \mathrm{M}$ Tris-HCl buffer ( $\mathrm{pH} 7.8$ ) containing $1 \mathrm{mM}$ EDTA, $1 \mathrm{mM}$ DTT and $4 \%$ insoluble polyvinylpyrrolidone, using sand and a mortar and pestle. To remove the sand, the homogenate was squeezed through a nylon mesh and centrifuged for $10 \mathrm{~min}$ at $20,000 \times g$ and $4{ }^{\circ} \mathrm{C}$. The glutathione reductase activity, based on the reduction of GSSG using NADPH, was measured spectrophotometrically in the supernatant at $25{ }^{\circ} \mathrm{C}[69]$.

\subsection{Statistical Analyses}

Prior to analysis, outliers were determined using the Extreme Studentised Deviate method (GraphPad Software, La Jolla, CA, USA) at significance level 0.05. Statistical analyses were performed in R version 3.3.1 (R Foundation for Statistical Computing, 2016, Vienna, Austria). Data were checked for both normal distribution (Shapiro-Wilk test) and homoscedasticity (Bartlett's test). In case these assumptions were not met, data were transformed (inverse, square root, logarithm, exponent) to achieve both normality and homoscedasticity of the data. The data were statistically analysed using a student's $t$-test or one-way ANOVA at significance level 0.05 . To correct for multiple comparisons, a post-hoc Tukey-Kramer test was used. If data were not normally distributed and/or homoscedastic, the non-parametric Kruskall-Wallis test was used in combination with the Wilcoxon rank sum test.

\section{Conclusions}

Our study on acute Cd-induced responses has put a subset of pressure points into perspective and elucidated, at least partly, the timing of these short-term responses (Figure 5). It is clear that root GSH depletion under Cd stress is the harbinger of a sequence of events. Moreover, we suggest that, corresponding to other studies, the root GSH depletion is a requirement for a proper Cd-induced alert response and, consequently, optimal acclimation. In this study we further substantiated previous findings that consider GSH as an important modulator of stress-induced $\mathrm{H}_{2} \mathrm{O}_{2}$ increases [29]. As both are central components of stress signalling, often acting in concert, the considered $\mathrm{H}_{2} \mathrm{O}_{2} / G S H$ ratio allowed us to obtain an integrative view on the plant's redox changes. Moreover, we show that, in case of Cd stress, $\mathrm{H}_{2} \mathrm{O}_{2}$ fluctuations are fine-tuned by the overall $\mathrm{GSH}$ pool rather than its redox state. The fact that, at the root level, only a subset of oxidative stress markers is upregulated, and this only after $24 \mathrm{~h}$ of exposure, further substantiates our suggestion that the early alterations observed 
in $\mathrm{H}_{2} \mathrm{O}_{2} / \mathrm{GSH}$ at the root level are required for a proper signalling response under $\mathrm{Cd}$ stress, rather than being merely a detrimental effect. The extent to which the redox balance in the apoplastic space is involved in the early responses to Cd exposure and, more specifically, serves in the sensing and propagation of redox signalling, needs further consideration. Finally, we put forward a model wherein the GSH-based alarming phase will help enhance root ethylene synthesis, derived from the rapidly increased ACC concentrations (Figure 5) [31]. This root-derived ethylene and/or ACC might function as a root-to-shoot signal that serves to optimise responses in the leaves, which eventually result in increased leaf GSH levels. This study revealed several aspects that are key in the early responses to $\mathrm{Cd}$ stress and serves as a stepping stone to future studies on key regulators of the Cd-induced alert response in view of the subsequent acclimation. The chicken or egg paradox concerning ethylene and GSH has yet to be further elucidated, and our data suggest that an even shorter exposure time frame allows for a clearer view on their interaction.

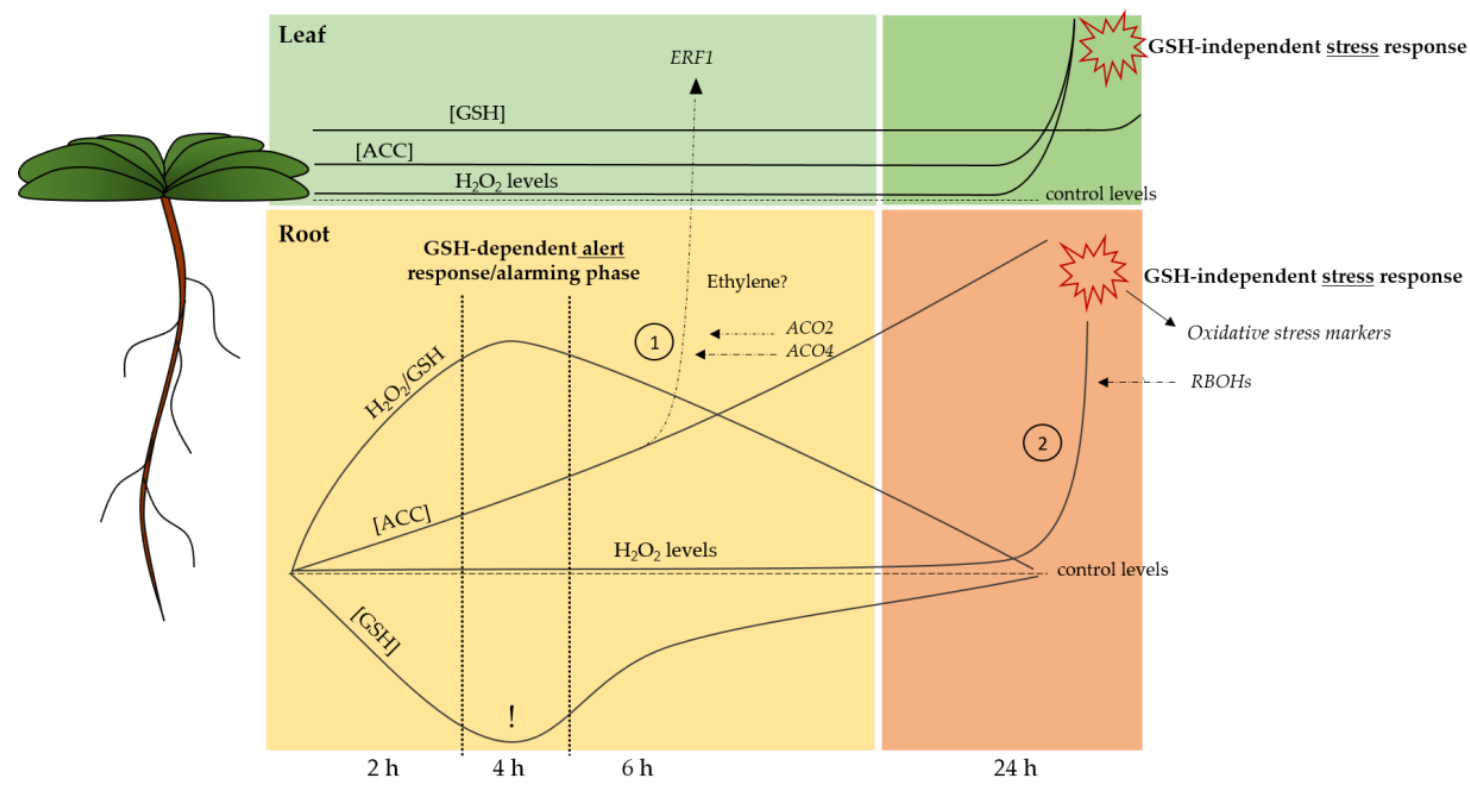

Figure 5. Proposed spatiotemporal timing for the identified pressure points that precede acclimation under cadmium (Cd) stress. (1) Roots serve as command centre, possibly via ethylene, to engage the leaves in an optimal response later on. (2) Stress persistence: responses are intensified via the increased expression of $\mathrm{RBOHs}$ and elevation of $\mathrm{H}_{2} \mathrm{O}_{2}$. This stress response is independent of glutathione (GSH). Full lines indicate $\mathrm{Cd}$-induced responses and dashed lines represent control levels. Dashed arrows refer to gene expression that possibly contributes to the Cd-induced response. Full arrows refer to $\mathrm{Cd}$-induced changes in gene expression as a result of the $\mathrm{Cd}$-induced response. ACC: 1-aminocyclopropane-1-carboxylic acid; $\mathrm{H}_{2} \mathrm{O}_{2}$ : hydrogen peroxide; ERF1: ethylene responsive transcription factor 1: ACO: ACC oxidase; $R B O H$ : respiratory burst oxidase homologue.

Supplementary Materials: Supplementary Materials can be found at http:/www.mdpi.com/1422-0067/21/17/ 6232/s1.

Author Contributions: All authors participated in the conceptualisation of this study and the design of the experiments. J.D. performed most experiments and wrote the manuscript. E.P. assisted with the A.C. measurements and analyses. A.C., S.H., E.P. and J.V. contributed with critical reviewing and advice. All authors have read and agreed to the published version of the manuscript.

Funding: This research was funded by the Research Foundation-Flanders (FWO) through a PhD grant fellowship for Jana Deckers $(1182220 N)$. Additional funding came from FWO projects to Ann Cuypers [grant numbers G0B6716N, G0C7518N].

Acknowledgments: We thank Sevgi Oden, Ann Wijgaerts and Carine Put for their expertise, assistance and technical support.

Conflicts of Interest: The authors declare no conflict of interest. 


\section{Abbreviations}

$\begin{array}{ll}\text { ACC } & \text { 1-aminocyclopropane-1-carboxylic acid } \\ \text { ACS } & \text { 1-aminocyclopropane-1-carboxylic acid synthase } \\ \text { ACO } & \text { 1-aminocyclopropane-1-carboxylic acid oxidase } \\ \text { AsA } & \text { Ascorbate } \\ \text { ATP } & \text { Adenosine triphosphate } \\ \text { Cd } & \text { Cadmium } \\ \text { eGSH } & \text { Extracellular glutathione } \\ \text { ERF } & \text { Ethylene responsive transcription factor } \\ \text { GGT } & \gamma \text {-glutamyl transpeptidase } \\ \text { GSH } & \text { Glutathione } \\ \text { GSH1 } & \text { Glutamate cysteine ligase } \\ \text { GSH2 } & \text { Glutathione synthetase } \\ \text { GOI } & \text { Gene of interest } \\ \text { GR } & \text { Glutathione reductase } \\ \mathrm{H}_{2} \mathrm{O}_{2} & \text { Hydrogen peroxide } \\ \text { MPK } & \text { Mitogen-activated protein kinase } \\ \text { NADPH } & \text { Nicotinamide adenine dinucleotide phosphate } \\ \mathrm{O}_{2}{ }^{\bullet-} & \text { Superoxide } \\ \text { OXI } & \text { Oxidative signal inducible } \\ \text { PC } & \text { Phytochelatine } \\ \text { RBOH } & \text { Respiratory burst oxidase homologue } \\ \text { ROS } & \text { Reactive oxygen species } \\ \text { RRTF } & \text { Redox-responsive transcription factor } \\ \text { SAM } & \text { S-adenosylmethionine } \\ \text { WRKY } & \text { WRKY DNA-binding protein } \\ \text { WT } & \text { Wild-type } \\ \text { ZAT } & \text { Zinc finger of Arabidopsis thaliana }\end{array}$

\section{References}

1. Grierson, C.S.; Barnes, S.R.; Chase, M.W.; Clarke, M.; Grierson, D.; Edwards, K.J.; Jellis, G.J.; Jones, J.D.; Knapp, S.; Oldroyd, G.; et al. One hundred important questions facing plant science research. New Phytol. 2011, 192, 6-12. [CrossRef] [PubMed]

2. Järup, L.; Berglund, M.; Elinder, C.G.; Nordberg, G.; Vanter, M. Health effects of cadmium exposure-a review of the literature and a risk estimate. Scand. J. Work Health 1998, 24, 1-51.

3. Verbruggen, N.; Hermans, C.; Schat, H. Mechanisms to cope with arsenic or cadmium excess in plants. Curr. Opin. Plant Biol. 2009, 12, 364-372. [CrossRef] [PubMed]

4. Di Toppi, L.S.; Gabbrielli, R. Response to cadmium in higher plants. Environ. Exp. Bot. 1999, 41, $105-130$. [CrossRef]

5. Asgher, M.; Khan, M.I.R.; Anjum, N.A.; Khan, N.A. Minimising toxicity of cadmium in plants-Role of plant growth regulators. Protoplasma 2014, 252, 399-413. [CrossRef]

6. Clemens, S.; Antosiewicz, D.M.; Ward, J.M.; Schachtman, D.P.; Schroeder, J.I. The plant cDNA LCT1 mediates the uptake of calcium and cadmium in yeast. Proc. Natl. Acad. Sci. USA 1998, 95, 12043-12048. [CrossRef]

7. Cuypers, A.; Plusquin, M.; Remans, T.; Jozefczak, M.; Keunen, E.; Gielen, H.; Opdenakker, K.; Nair, A.R.; Munters, E.; Artois, T.J.; et al. Cadmium stress: An oxidative challenge. Biometals 2010, 23, 927-940. [CrossRef]

8. Cuypers, A.; Smeets, K.; Ruytinx, J.; Opdenakker, K.; Keunen, E.; Remans, T.; Horemans, N.; Vanhoudt, N.; Van Sanden, S.; Van Belleghem, F.; et al. The cellular redox state as a modulator in cadmium and copper responses in Arabidopsis thaliana seedlings. J. Plant Physiol 2011, 168, 309-316. [CrossRef]

9. Semane, B.; Cuypers, A.; Smeets, K.; Van Belleghem, F.; Horemans, N.; Schat, H.; Vangronsveld, J. Cadmium responses in Arabidopsis thaliana: Glutathione metabolism and antioxidative defence system. Physiol. Plant. 2007, 129, 519-528. [CrossRef] 
10. Jozefczak, M.; Keunen, E.; Schat, H.; Bliek, M.; Hernandez, L.E.; Carleer, R.; Remans, T.; Bohler, S.; Vangronsveld, J.; Cuypers, A. Differential response of Arabidopsis leaves and roots to cadmium: Glutathione-related chelating capacity vs. antioxidant capacity. Plant Physiol Biochem 2014, 83, 1-9. [CrossRef]

11. Jozefczak, M.; Bohler, S.; Schat, H.; Horemans, N.; Guisez, Y.; Remans, T.; Vangronsveld, J.; Cuypers, A. Both the concentration and redox state of glutathione and ascorbate influence the sensitivity of arabidopsis to cadmium. Ann. Bot. 2015, 116, 601-612. [CrossRef] [PubMed]

12. Hell, R.; Bergmann, L. $\gamma$-Glutamylcysteine synthetase in higher plants: Catalytic properties and subcellular localization. Planta 1990, 180, 603-612. [CrossRef] [PubMed]

13. Law, M.Y.; Halliwell, B. Purification and properties of glutathione synthetase from spinach (Spinacia oleracea) leaves. Plant Sci. 1986, 43, 185-191. [CrossRef]

14. Hell, R.; Bergmann, L. Glutathione synthetase in tobacco suspension cultures: Catalytic properties and localization. Physiol. Plant. 1988, 72, 70-76. [CrossRef]

15. Grill, E.; Winnacker, E.-L.; Zenk, M.H. Phytochelatins: The Principal Heavy-Metal Complexing Peptides of Higher Plants. Science 1985, 230, 674-676. [CrossRef]

16. Groden, D.; Beck, E. $\mathrm{H}_{2} \mathrm{O}_{2}$ destruction by ascorbate-dependent systems from chloroplasts. Biochim. Biophys. Acta Bioenerg. 1979, 546, 426-435. [CrossRef]

17. Foyer, C.H.; Noctor, G. Redox homeostasis and antioxidant signaling: A metabolic interface between stress perception and physiological responses. Plant Cell 2005, 17, 1866-1875. [CrossRef]

18. Gill, S.S.; Anjum, N.A.; Hasanuzzaman, M.; Gill, R.; Trivedi, D.K.; Ahmad, I.; Pereira, E.; Tuteja, N. Glutathione and glutathione reductase: A boon in disguise for plant abiotic stress defense operations. Plant Physiol. Biochem. 2013, 70, 204-212. [CrossRef]

19. Mhamdi, A.; Hager, J.; Chaouch, S.; Queval, G.; Han, Y.; Taconnat, L.; Saindrenan, P.; Gouia, H.; Issakidis-Bourguet, E.; Renou, J.P.; et al. Arabidopsis Glutathione Reductase1 plays a crucial role in leaf responses to intracellular hydrogen peroxide and in ensuring appropriate gene expression through both salicylic acid and jasmonic acid signaling pathways. Plant Physiol 2010, 153, 1144-1160. [CrossRef]

20. Masi, A.; Trentin, A.R.; Agrawal, G.K.; Rakwal, R. Gamma-glutamyl cycle in plants: A bridge connecting the environment to the plant cell? Front. Plant Sci. 2015, 6, 252. [CrossRef]

21. Tolin, S.; Arrigoni, G.; Trentin, A.R.; Veljovic-Jovanovic, S.; Pivato, M.; Zechman, B.; Masi, A. Biochemical and quantitative proteomics investigations in Arabidopsis ggt1 mutant leaves reveal a role for the gamma-glutamyl cycle in plant's adaptation to environment. Proteomics 2013, 13, 2031-2045. [CrossRef] [PubMed]

22. Tamás, L.; Alemayehu, A.; Mistrík, I.; Zelinová, V. Extracellular glutathione recycling by $\gamma$-glutamyl transferase in barley root tip exposed to cadmium. Environ. Exp. Bot. 2015, 118, 32-39. [CrossRef]

23. Destro, T.; Prasad, D.; Martignago, D.; Bernet, I.L.; Trentin, A.R.; Renu, I.K.; Ferretti, M.; Masi, A. Compensatory expression and substrate inducibility of gamma-glutamyl transferase GGT2 isoform in Arabidopsis thaliana. J. Exp. Bot. 2011, 62, 805-814. [CrossRef] [PubMed]

24. Ohkama-Ohtsu, N.; Radwan, S.; Peterson, A.; Zhao, P.; Badr, A.F.; Xiang, C.; Oliver, D.J. Characterization of the extracellular $\gamma$-glutamyl transpeptidases, GGT1 and GGT2, in Arabidopsis. Plant J. 2007, 49, 865-877. [CrossRef] [PubMed]

25. Martin, M.N.; Saladores, P.H.; Lambert, E.; Hudson, A.O.; Leustek, T. Localization of members of the gamma-glutamyl transpeptidase family identifies sites of glutathione and glutathione S-conjugate hydrolysis. Plant Physiol 2007, 144, 1715-1732. [CrossRef] [PubMed]

26. Ferretti, M.; Destro, T.; Tosatto, S.C.E.; La Rocca, N.; Rascio, N.; Masi, A. Gamma-glutamyl transferase in the cell wall participates in extracellular glutathione salvage from the root apoplast. New Phytol. 2009, 181, 115-126. [CrossRef]

27. Mittler, R.; Vanderauwera, S.; Suzuki, N.; Miller, G.; Tognetti, V.B.; Vandepoele, K.; Gollery, M.; Shulaev, V.; Van Breusegem, F. ROS signaling: The new wave? Trends Plant Sci 2011, 16, 300-309. [CrossRef]

28. Cuypers, A.; Hendrix, S.; dos Reis, R.A.; De Smet, S.; Deckers, J.; Gielen, H.; Jozefczak, M.; Loix, C.; Vercampt, H.; Vangronsveld, J.; et al. Hydrogen peroxide, signaling in disguise during metal phytotoxicity. Front. Plant Sci. 2016, 7, 470. [CrossRef]

29. Han, Y.; Chaouch, S.; Mhamdi, A.; Queval, G.; Zechmann, B.; Noctor, G. Functional analysis of Arabidopsis mutants points to novel roles for glutathione in coupling $\mathrm{H}_{2} \mathrm{O}_{2}$ to activation of salicylic acid accumulation and signaling. Antioxid. Redox Signal. 2013, 18, 2106-2121. [CrossRef] 
30. Schnaubelt, D.; Queval, G.; Dong, Y.; Diaz-Vivancos, P.; Makgopa, M.E.; Howell, G.; De Simone, A.; Bai, J.; Hannah, M.A.; Foyer, C.H. Low glutathione regulates gene expression and the redox potentials of the nucleus and cytosol in Arabidopsis thaliana. Plant Cell Environ. 2015, 38, 266-279. [CrossRef]

31. Schellingen, K.; Van Der Straeten, D.; Remans, T.; Vangronsveld, J.; Keunen, E.; Cuypers, A. Ethylene signalling is mediating the early cadmium-induced oxidative challenge in Arabidopsis thaliana. Plant Sci. 2015, 239, 137-146. [CrossRef] [PubMed]

32. Mersmann, S.; Bourdais, G.; Rietz, S.; Robatzek, S. Ethylene Signaling Regulates Accumulation of the FLS2 Receptor and Is Required for the Oxidative Burst Contributing to Plant Immunity. Plant Physiol. 2010, 154, 391-400. [CrossRef] [PubMed]

33. Montero-Palmero, M.B.; Martín-Barranco, A.; Escobar, C.; Hernández, L.E. Early transcriptional responses to mercury: A role for ethylene in mercury-induced stress. New Phytol. 2014, 201, 116-130. [CrossRef] [PubMed]

34. Chen, H.J.; Huang, C.S.; Huang, G.J.; Chow, T.J.; Lin, Y.H. NADPH oxidase inhibitor diphenyleneiodonium and reduced glutathione mitigate ethephon-mediated leaf senescence, $\mathrm{H}_{2} \mathrm{O}_{2}$ elevation and senescence-associated gene expression in sweet potato (Ipomoea batatas). J. Plant Physiol 2013, 170, 1471-1483. [CrossRef]

35. Schellingen, K.; Van Der Straeten, D.; Vandenbussche, F.; Prinsen, E.; Remans, T.; Vangronsveld, J.; Cuypers, A. Cadmium-induced ethylene production and responses in Arabidopsis thaliana rely on ACS2 and ACS6 gene expression. BMC Plant Biol. 2014, 14, 1-14. [CrossRef] [PubMed]

36. Argueso, C.T.; Hansen, M.; Kieber, J.J. Regulation of ethylene biosynthesis. J. Plant Growth Regul. 2007, 26, 92-105. [CrossRef]

37. Lin, Z.; Zhong, S.; Grierson, D. Recent advances in ethylene research. J. Exp. Bot. 2009, 60, 3311-3336. [CrossRef]

38. Rentel, M.C.; Lecourieux, D.; Ouaked, F.; Usher, S.L.; Petersen, L.; Okamoto, H.; Knight, H.; Peck, S.C.; Grierson, C.S.; Hirt, H.; et al. OXI1 kinase is necessary for oxidative burst-mediated signalling in Arabidopsis. Nature 2004, 427, 858-861. [CrossRef]

39. Müller, M.; Munné-Bosch, S. Ethylene Response Factors: A Key Regulatory Hub in Hormone and Stress Signaling. Plant Physiol. 2015, 169, 32-41. [CrossRef]

40. Smeets, K.; Ruytinx, J.; Van Belleghem, F.; Semane, B.; Lin, D.; Vangronsveld, J.; Cuypers, A. Critical evaluation and statistical validation of a hydroponic culture system for Arabidopsis thaliana. Plant Physiol. Biochem. 2008, 46, 212-218. [CrossRef]

41. Keunen, E.; Truyens, S.; Bruckers, L.; Remans, T.; Vangronsveld, J.; Cuypers, A. Survival of Cd-exposed Arabidopsis thaliana: Are these plants reproductively challenged? Plant Physiol. Biochem. 2011, 49, 1084-1091. [CrossRef] [PubMed]

42. Wong, C.K.E.; Cobbett, C.S. HMA P-type ATPases are the major mechanism for root-to-shoot Cd translocation in Arabidopsis thaliana. New Phytol. 2009, 181,71-78. [CrossRef] [PubMed]

43. Gadjev, I.; Vanderauwera, S.; Gechev, T.S.; Laloi, C.; Minkov, I.N.; Shulaev, V.; Apel, K.; Inze, D.; Mittler, R.; Van Breusegem, F. Transcriptomic footprints disclose specificity of reactive oxygen species signaling in Arabidopsis. Plant Physiol. 2006, 141, 436-445. [CrossRef]

44. Remans, T.; Opdenakker, K.; Smeets, K.; Mathijsen, D.; Vangronsveld, J.; Cuypers, A. Metal-specific and NADPH oxidase dependent changes in lipoxygenase and NADPH oxidase gene expression in Arabidopsis thaliana exposed to cadmium or excess copper. Funct. Plant Biol. 2010, 37, 532-544. [CrossRef]

45. Foyer, C.H.; Lopez-Delgado, H.; Dat, J.F.; Scott, I.M. Hydrogen peroxide- and glutathione-associated mechanisms of acclimatory stress tolerance and signalling. Physiol. Plant. 1997, 100, 241-254. [CrossRef]

46. Keunen, E.; Schellingen, K.; Vangronsveld, J.; Cuypers, A. Ethylene and metal stress: Small molecule, big impact. Front. Plant Sci. 2016, 7, 23. [CrossRef]

47. Van de Poel, B.; Van Der Straeten, D. 1-aminocyclopropane-1-carboxylic acid (ACC) in plants: More than just the precursor of ethylene! Front. Plant Sci. 2014, 5, 640. [CrossRef]

48. Lambers, H.; Chapin, F.S.; Pons, T.L. Plant Physiological Ecology, 1st ed.; Springer: New York, NY, USA, 1998; pp. 1-540.

49. Tausz, M.; Šircelj, H.; Grill, D. The glutathione system as a stress marker in plant ecophysiology: Is a stress-response concept valid? J. Exp. Bot. 2004, 55, 1955-1962. [CrossRef] 
50. Zagorchev, L.; Seal, C.E.; Kranner, I.; Odjakova, M. A central role for thiols in plant tolerance to abiotic stress. Int. J. Mol. Sci. 2013, 14, 7405-7432. [CrossRef]

51. Li, Y.; Dhankher, O.P.; Carreira, L.; Balish, R.S.; Meagher, R.B. Arsenic and mercury tolerance and cadmium sensitivity in Arabidopsis plants expressing bacterial $\gamma$-glutamylcysteine synthetase. Environ. Toxicol. Chem. 2005, 24, 1376-1386. [CrossRef]

52. Xiang, C.; Werner, B.L.; Christensen, E.M.; Oliver, D.J. The biological functions of glutathione revisited in Arabidopsis transgenic plants with altered glutathione levels. Plant Physiol. 2001, 126, 564-574. [CrossRef] [PubMed]

53. Zlobin, I.E.; Kartashov, A.V.; Shpakovski, G.V. Different roles of glutathione in copper and zinc chelation in Brassica napus roots. Plant Physiol. Biochem. 2017, 118, 333-341. [CrossRef] [PubMed]

54. Bankaji, I.; Caçador, I.; Sleimi, N. Physiological and biochemical responses of Suaeda fruticosa to cadmium and copper stresses: Growth, nutrient uptake, antioxidant enzymes, phytochelatin, and glutathione levels. Environ. Sci. Pollut. Res. 2015, 22, 13058-13069. [CrossRef] [PubMed]

55. Xiang, C.; Oliver, D.J. Glutathione Metabolic Genes Coordinately Respond to Heavy Metals and Jasmonic Acid in Arabidopsis. Plant Cell 1998, 10, 1539-1550. [CrossRef]

56. Chen, J.; Yang, L.; Yan, X.; Liu, Y.; Wang, R.; Fan, T.; Ren, Y.; Tang, X.; Xiao, F.; Liu, Y.; et al. Zinc-Finger Transcription Factor ZAT6 Positively Regulates Cadmium Tolerance through the Glutathione-Dependent Pathway in Arabidopsis. Plant Physiol. 2016, 171, 707-719. [CrossRef]

57. Jozefczak, M.; Remans, T.; Vangronsveld, J.; Cuypers, A. Glutathione is a key player in metal-induced oxidative stress defenses. Int. J. Mol. Sci. 2012, 13, 3145-3175. [CrossRef]

58. Masi, A.; Destro, T.; Turetta, L.; Varotto, S.; Caporale, G.; Ferretti, M. Localization of gamma-glutamyl transferase activity and protein in Zea mays organs and tissues. J. Plant Physiol. 2007, 164, 1527-1535. [CrossRef]

59. Xi, H.; Xu, H.; Xu, W.; He, Z.; Xu, W.; Ma, M. A SAL1 Loss-of-Function Arabidopsis Mutant Exhibits Enhanced Cadmium Tolerance in Association with Alleviation of Endoplasmic Reticulum Stress. Plant Cell Physiol. 2016. [CrossRef]

60. Uzilday, B.; Ozgur, R.; Sekmen, A.H.; Turkan, I. Endoplasmic reticulum stress regulates glutathione metabolism and activities of glutathione related enzymes in Arabidopsis. Funct. Plant Biol. 2018, 45, 284-296. [CrossRef]

61. Matsuo, M.; Johnson, J.M.; Hieno, A.; Tokizawa, M.; Nomoto, M.; Tada, Y.; Godfrey, R.; Obokata, J.; Sherameti, I.; Yamamoto, Y.Y.; et al. High REDOX RESPONSIVE TRANSCRIPTION FACTOR1 Levels Result in Accumulation of Reactive Oxygen Species in Arabidopsis thaliana Shoots and Roots. Mol. Plant 2015, 8 , 1253-1273. [CrossRef]

62. Joo, S.; Liu, Y.; Lueth, A.; Zhang, S. MAPK phosphorylation-induced stabilization of ACS6 protein is mediated by the non-catalytic C-terminal domain, which also contains the cis-determinant for rapid degradation by the 26S proteasome pathway. Plant J. 2008, 54, 129-140. [CrossRef] [PubMed]

63. Li, G.; Meng, X.; Wang, R.; Mao, G.; Han, L.; Liu, Y.; Zhang, S. Dual-Level Regulation of ACC Synthase Activity by MPK3/MPK6 Cascade and Its Downstream WRKY Transcription Factor during Ethylene Induction in Arabidopsis. PLoS Genet. 2012, 8, e1002767. [CrossRef] [PubMed]

64. Skottke, K.R.; Yoon, G.M.; Kieber, J.J.; DeLong, A. Protein Phosphatase 2A Controls Ethylene Biosynthesis by Differentially Regulating the Turnover of ACC Synthase Isoforms. PLoS Genet. 2011, 7, e1001370. [CrossRef]

65. Remans, T.; Smeets, K.; Opdenakker, K.; Mathijsen, D.; Vangronsveld, J.; Cuypers, A. Normalisation of real-time RT-PCR gene expression measurements in Arabidopsis thaliana exposed to increased metal concentrations. Planta 2008, 227, 1343-1349. [CrossRef]

66. Bustin, S.A.; Benes, V.; Garson, J.A.; Hellemans, J.; Huggett, J.; Kubista, M.; Mueller, R.; Nolan, T.; Pfaffl, M.W.; Shipley, G.L.; et al. The MIQE guidelines: Minimum information for publication of quantitative real-time PCR experiments. Clin. Chem. 2009, 55, 611-622. [CrossRef]

67. Queval, G.; Noctor, G. A plate reader method for the measurement of NAD, NADP, glutathione, and ascorbate in tissue extracts: Application to redox profiling during Arabidopsis rosette development. Anal. Biochem. 2007, 363, 58-69. [CrossRef] 
68. Smets, R.; Claes, V.; Van Onckelen, H.A.; Prinsen, E. Extraction and quantitative analysis of 1-aminocyclopropane-1-carboxylic acid in plant tissue by gas chromatography coupled to mass spectrometry. J. Chromatogr. A 2003, 993, 79-87. [CrossRef]

69. Cuypers, A.; Vangronsveld, J.; Clijsters, H. Biphasic effect of copper on the ascorbate-glutathione pathway in primary leaves of Phaseolus vulgaris seedlings during the early stages of metal assimilation. Physiol. Plant. 2000, 110, 512-517. [CrossRef]

(C) 2020 by the authors. Licensee MDPI, Basel, Switzerland. This article is an open access article distributed under the terms and conditions of the Creative Commons Attribution (CC BY) license (http://creativecommons.org/licenses/by/4.0/). 